\title{
High mountains in a zone of extended crust: Insights into the Neogene-Quaternary topographic development of northeastern Iberia
}

\author{
Claudia J. Lewis \\ Los Alamos National Laboratory, Los Alamos, New Mexico \\ Jaume Vergés \\ Institute of Earth Sciences "Jaume Almera," Consejo Superior de Investigaciones Cientificas, Barcelona, Spain
}

Mariano Marzo

Departament d'Estratıgrafia 1 Paleontologia, Universitat de Barcelona, Barcelona, Spain

\begin{abstract}
Topographic analysis combined with geological and geophysical observations indicate that much of the present configuration of the northeastern Iberian Peninsula derives from Neogene-Quaternary opening of the western Mediterranean basins following the Pyrenean orogeny. Mountainous topography up to $2000 \mathrm{~m}$ lines the Mediterranean coastal margin of Cataluña (Spain) despite a crustal thickness of $22 \mathrm{~km}$ at the coast. Geometric analysis of topographic profiles indicates a strong link between topography and extensional tectonics. Trends in maximum, mean and minimum elevations show marked regional increases in a SW-NE direction along the axis of the Ebro basin towards the active Amer-Brugent normal fault. From patterns of local relief, characteristics of the fluvial drainage network, location of drainage divides, and degree of escarpment retreat, we distinguish two overlapping areas of mountainous topography, a southern area related to late Oligocene to middle Miocene rifting and a northern area related to late Miocene to Quaternary rifting. The youthful topography in the northern area likely results from mechanical unloading of the footwall of the Amer-Brugent normal fault. In the southern area (encompassing the Catalan Coastal Ranges), erosion contınuously renews topography produced by rifting while causing headward erosion of coastal rivers into the Ebro basin. Elevated topography along the Catalan margin derives principally from flexural isostatic rebound due to tectonic and erosional denudation, causing exhumation of the rifted margin. Nonetheless, the height of the mountains and the thinness of the crust suggest an additional component of dynamic or thermal support of mountainous topography, likely buoyancy forces from density differences in the mantle.
\end{abstract}

\section{Introduction}

Geoscientists working in northeastern Spain have for many years remarked upon the apparent inconsistency of high mountain ranges along the northeastern coast of Spain and marked crustal

Copyright 2000 by the American Geophysical Union.

Paper number $1.999 \mathrm{TC} 900056$. 0278-7407/00/1999TC900056\$09.00 thinning [e.g., Watts and Torné, 1992; Janssen et al., 1993], evident in the pattern of Bouguer gravity anomalies [Casas et al., 1986] and in seismic refraction data (Figures 1 and 2) [Daignières et al., 1982; Pascal et al., 1992; Torné et al., 1996]. Two principal hypotheses have been advanced in recent years to explain the high topography of the Catalan Coastal Ranges and the Transverse Ranges (Figure 3): (1) thermal uplift due to lithospheric thinning and (2) mechanical uplift of rift shoulders due to flexural buoyancy forces. Numerous authors have invoked a Pliocene-Recent thermal event to explain "uplifted" marine strata or high topography, unequal crustal and lithospheric thinning values, and high surface heat flow at the Catalan margin [e.g., Foucher et al., 1992; Morgan and Fernàndez, 1992]. By contrast, models applied to this region incorporating lithospheric necking, flexural backstripping, and lithospheric buoyancy suggest that the Catalan margin of the València trough flexed upward syntectonically, owing to isostatic restoring forces, creating rift shoulder topography [e.g., Morgan and Fernàndez, 1992; Watts and Torné, 1992; Janssen et al., 1993].

To better understand the origin of high topography along the northeastern coast of Spain, we can draw on extensive published research on rifted margins which clarifies the link between rift structures and geomorphic features such as elevated or incised topography. The problem of rifted- margın uplifts has been investigated intensively within the last 10 years, both in areas of active extension [e.g., Ebinger et al., 1989; Wetssel and Karner, 1989; van der Beek et al., 1994, 1995] and at passive margins [e.g., Stephenson and Lambeck, 1985; Gilchrist and Summerfield, 1990; Gilchrist et al., 1994; Tucker and Slingerland, 1994]. Rift flank uplift is a widely observed phenomenon which has been attributed to a variety of transient (dynamic and thermal) and permanent (tectonic and geomorphic) causes [Weissel and Karner, 1989; Kooi et al., 1992].

"Permanent" uplift of rift flanks results from flexural isostatic rebound of the lithosphere following tectonic denudation [e.g., Weissel and Karner, 1989]. Many recent studies have shown that erosion plays a significant role in maintaining elevated topography produced by rifting [e.g., Stephenson and Lambeck, 1985; van der Beek et al., 1995]. Investigations of mature rifted margins have shown that rift- flank uplifts can be very long-lived features [e.g., Stephenson and Lambeck, 1985; Gilchrist and 


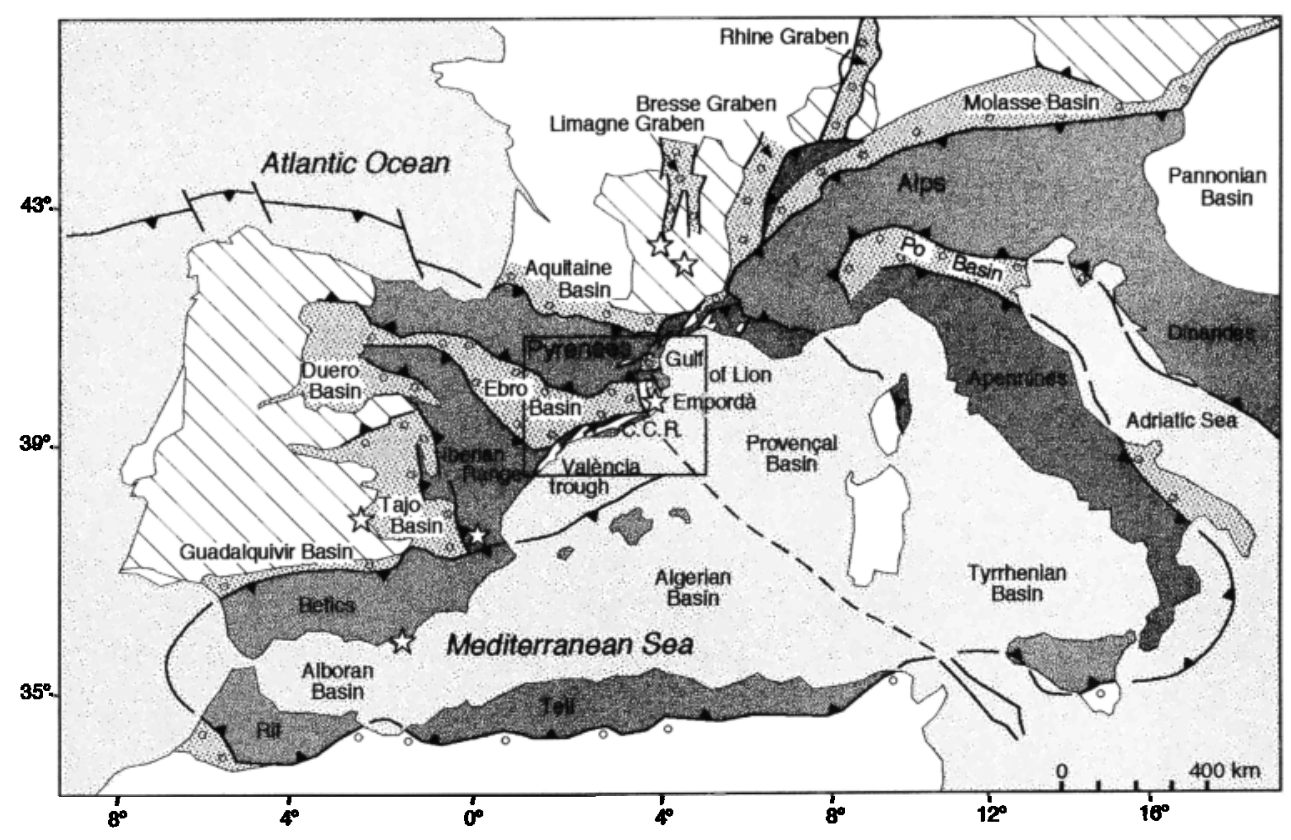

Figure 1. Map showing the principal tectonic elements of the western Mediterranean region. The modern plate boundary between the European and African plates is complex and includes thrust faults of the Betic and Rif Cordillera and the Apennines as well as extensional faults of the Alboran and Tyrrhenian basins. Patterns are as follows: heavily shaded, contractional orogens ( $\sim 80-0 \mathrm{Ma})$; dotted, Tertiary sedimentary basins; ruled, Hercynian ( $\sim 360-325 \mathrm{Ma})$ crystalline massifs. Stars indicate areas of Quaternary volcanism. Heavy lines with triangles indicate major thrust faults of contractional orogens; heavy lines without triangles indicate extensional faults of the western European rift system ( 32-0 Ma). Box encloses approximate area of Figures 2-5. CCR, Catalan Coastal Ranges.

Summerfield, 1990; Tucker and Slingerland, 1994]. Many of the passive margins of the Gondwana continents, for example, are characterized by major erosional escarpments separating coastal plains from interior plateaus. These escarpments originate by mechanical unloading and isostatic rebound of the lithosphere during extension. Subsequently, erosion renews the elevated topography while at the same time causing retreat of the escarpments well into the continent. This process operates independently of the mechanics of rifting.

Dynamic forces in continental rifts may be generated by horizontal lithospheric extension [Parmentier, 1987], fluctuations in intraplate stress fields due to plate boundary processes [Kooi et al., 1992], or convective heating of the lithosphere. All of these processes may give rise to topography. Heating of the lithosphere above a region of convecting asthenosphere results in differential normal stresses (buoyancy forces) exerted on the base of the lithosphere and ensuing surface uplift [Houseman and England, 1986]. Lateral temperature gradients associated with hot, lowdensity asthenospheric anomalies (arising from either active or passive upwelling) induce convection, which then transmits normal stresses to the overlying plate and creates topography whose mass balances the buoyancy of the low-density anomalies [Buck, 1986]. Dynamically supported rift flanks decay as dynamic forces diminish [Parmentier, 1987]. Thermally supported rift flanks disappear with cessation of rifting, decay of the thermal anomaly, and ensuing thermal contraction and subsidence [e.g., Buck, 1986; Buck et al., 1988; Wdowinski and Axen, 1992].
Despite intensive modeling efforts, no attempt has yet been made to examine the relationship among youthful topography in northeastern Spain, regional structural patterns, and geodynamic processes. Nor have systematic efforts been made to compare this area with other well-studied rifted margins for insight into the origin of the distinctive geomorphic features in northeastern Spain. Our aim in this paper is to document the lateral extent and geometry of elevated and incised topography. We also look to the modern river drainage system for clues as to the mechanism for "uplift" of coastal mountain ranges. We combine our results with published regional geological and geophysical data to constrain geodynamic models for this area.

\section{Geologic Setting}

\subsection{Eocene to late Oligocene Contraction}

The study area encompasses parts of two contractional orogens, the Pyrenees and the Catalan Coastal Ranges (Figure 1, which formed by continent-continent collision and partial subduction of the Iberian plate beneath the European plate [ECORS-Pyrenees Team, 1988; Choukroune and ECORS Pyrenees Team, 1989; Roure et al., 1989; Muñoz, 1992] from Late Cretaceous to Oligocene-early Miocene time [Puigdefabregas and Souquet, 1986]. The Pyrenean orogen is an asymmetrical, double-wedge continental belt that formed at the boundary of two continental plates, whereas the Catalan Coastal Ranges, whose growth was dominated by basement-involved 


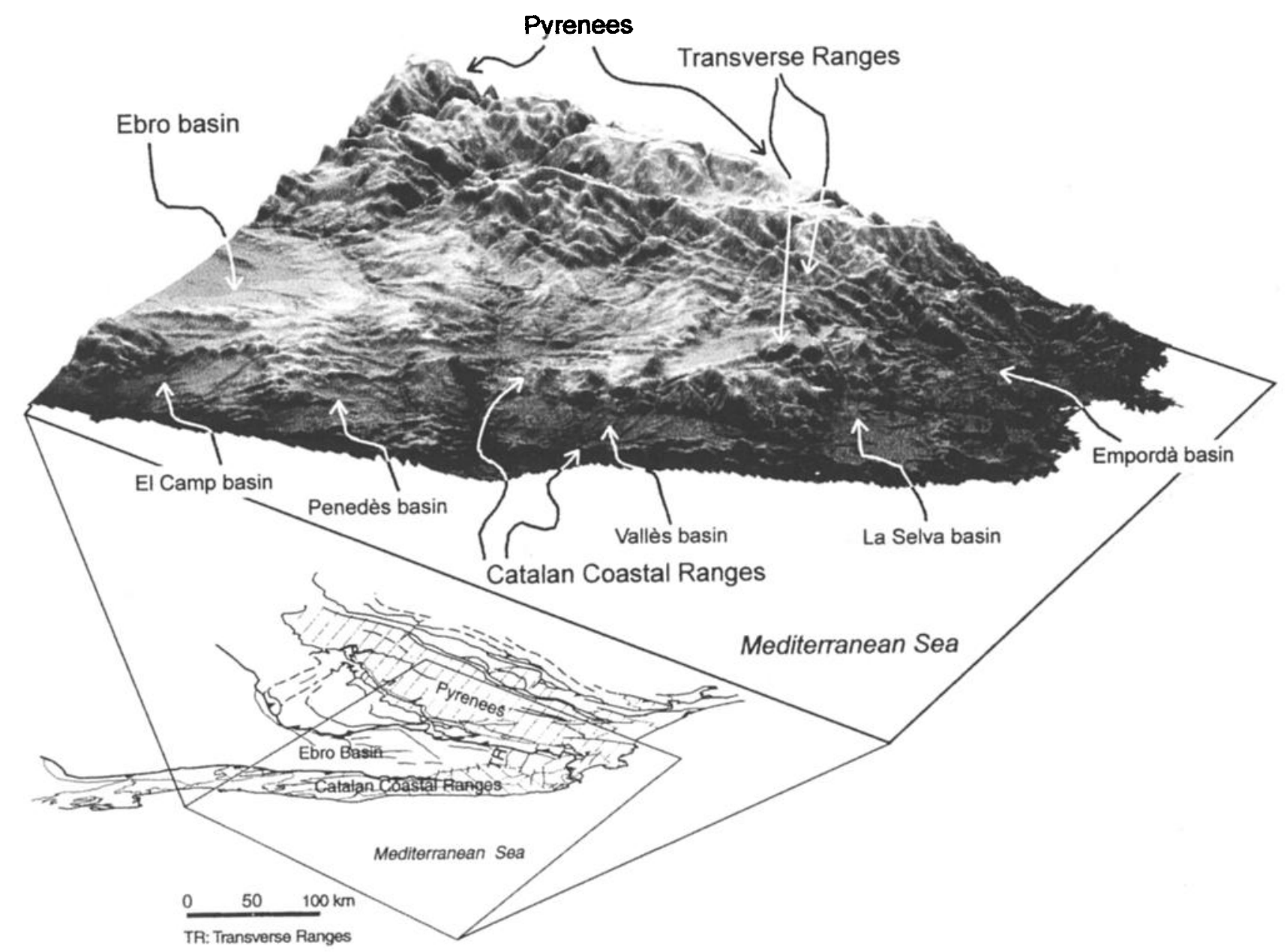

Figure 2. Topography of northeastern Spain based on Digital Elevation Model GTOPO30 from the U.S. Geological Survey with a grid spacing of $\sim 1 \mathrm{~km}$. This three-dimensional view was constructed by interpolating data every $300 \mathrm{~m}$. The point of view is from the SE to emphasize the intersection between the early-middle Miocene set of NE-SW striking normal faults and the late Miocene-Recent set of NW-SE striking normal faults. The Montseny basement massif, with elevations up to $1700 \mathrm{~m}$, is located in the footwall of two intersecting, orthogonal and active normal faults.

thrust tectonics [e.g., Guimerà, 1984; Anadón et al., 1985], developed in the interior of the Iberian plate. A minimum of 125 $\mathrm{km}$ of total shortening occurred across the eastern Pyrenees [Vergés et al., 1995], and a maximum of a few tens of kilometers of shortening occurred across the Catalan Coastal Ranges.

Although not preserved, the obliquity of the Pyrenees and the Catalan Coastal Ranges suggests an intersection of the two thrust belts in the vicinity of the present-day Gulf of Roses (Figure 3) [Riba et al., 1983; Tassone et al., 1994]. During early to middle Eocene time, the southeastern part of the Ebro foreland basin developed primarily by regional subsidence related to emplacement of Pyrenean thrust sheets [e.g., Vergés et al., 1998]. With the onset of frontal thrusting in the Catalan Coastal Ranges at $41.2 \mathrm{Ma}$, the rate of subsidence increased along the basin's southeastern margin [Vergés et al., 1998]. The middle Eocene Ebro basin was characterized by a belt of fan- deltas derived from the Pyrenees in the north, the Catalan Coastal Ranges in the southeast, and the intersection of the two chains in the east [Vergés, 1993; Vergés and Burbank, 1996].

\subsection{Late Oligocene to Middle Miocene Extension}

In addition to the contractional orogens of the Pyrenees and the Catalan Coastal Ranges, the study area borders extensional basins of the Cenozoic European Rift System, including the València trough, the Gulf of Lion, and the Provençal basin, and encompasses extensional basins of the Catalan margin (Figures 1 and 2). Within the València trough, two major stages of subsidence are recognized, one between 30 and $15 \mathrm{Ma}$, coeval with structural formation of the trough and characterized by active rifting and rapid subsidence, and the other from $15 \mathrm{Ma}$ to the present, characterized by less faulting and slowly decreasing subsidence [Roca and Desegaulx, 1992]. Minimal volcanism was associated with rifting of the València trough [Marti et al., 


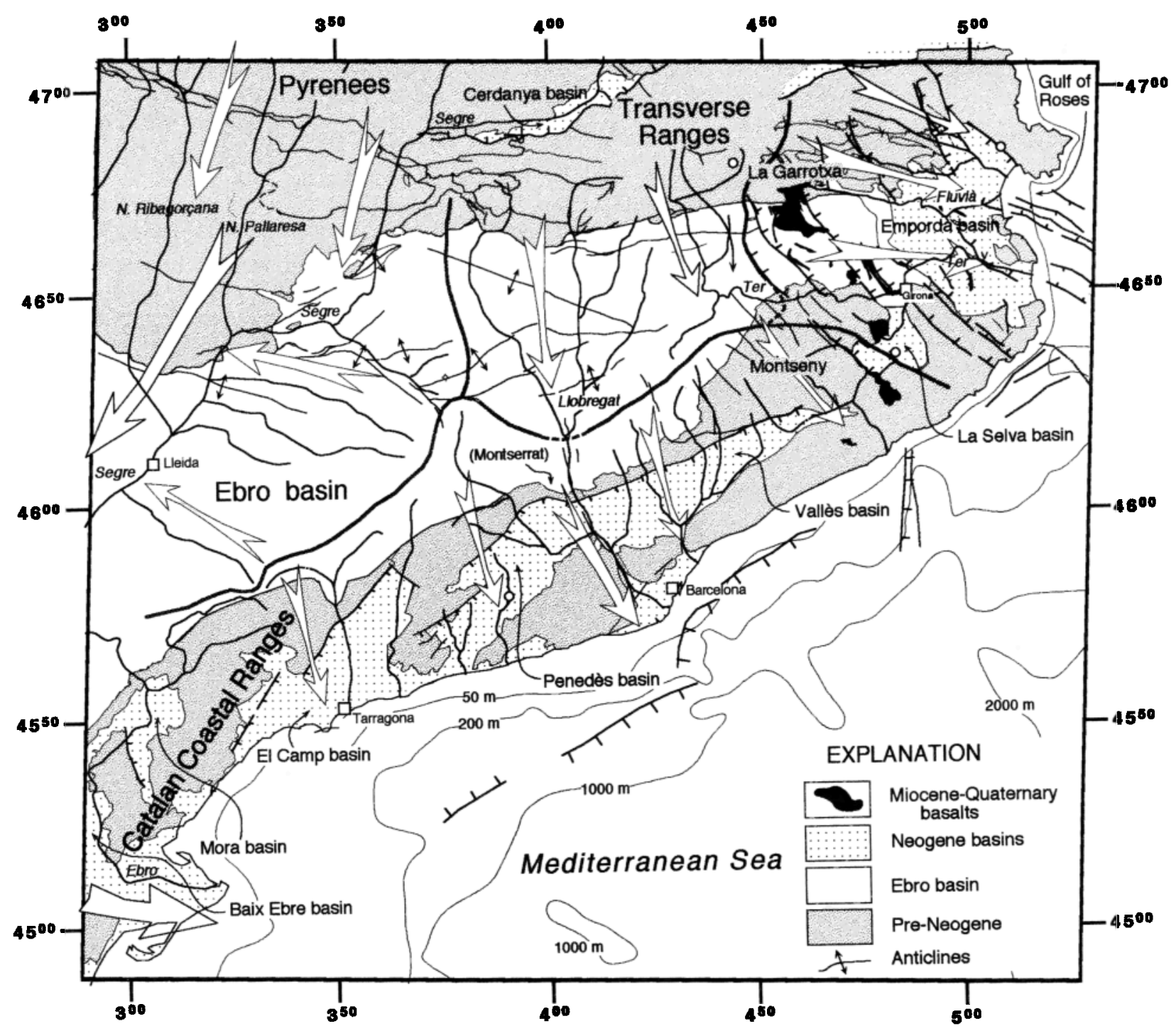

Figure 3. Rivers and drainage divides on geologic map of northeastern Spain. The contractional orogens of the Pyrenees and Catalan Coastal Ranges are shown along with the Ebro foreland basin and the extensional basins of the Catalan margin (E1 Camp, Vallès-Penedès, and Empordà basins). Heavy solid lines are drainage divides. Lighter solid lines are rivers. Large open arrows indicate principal drainage directions. Solid lines with hachures are Neogene extensional faults of the Catalan margin and València trough. Lightest solid lines are Pyrenean age thrust faults, fold axes, and strike-slip faults. Contour lines offshore indicate prominent submarine canyons.

1992]. Extension in the Gulf of Lion (Figure 1) began somewhat earlier than in the València trough [Cravatte et al., 1974; Gorini et al., 1993; Mauffret et al., 1995], ended 23-24 Ma [Cherchi and Montadert, 1982] or at $\sim 21 \mathrm{Ma}$ [Rehault et al., 1984], and culminated in seafloor spreading in the Provençal basin and rotation of the continental sliver comprising Corsica and Sardinia (Figure 1). The onset and duration of seafloor spreading are still debated, though estimates range from 23-19 Ma [Montigny et al., 1981; Cherchi and Montadert, 1982], from 21 to $18 \mathrm{Ma}$ [Rehault et al., 1984], and from 21 to $15 \mathrm{Ma}$ [Vigliotti and Langenheim, 1995].

Though controversy exists regarding the origin of late Oligocene to middle Miocene extension in the western
Mediterranean, a commonly held view is that passive rifting behind a west dipping, retreating subduction zone pulled Corsica and Sardinia eastward and the Kabylies domain (now part of the Tell tectonic unit; Figure 1) southward along with the retreating parts of the upper plate [e.g., Alvarez et al., 1974; Royden, 1993; Lonergan and White, 1997; Vergés and Sàbat, in press]. This process may have been assisted by reorientation of the regional stress system in latest Oligocene-early Miocene time [Dewey et al., 1989; Vázquez et al., 1993] as the triple junction between North America, Eurasia, and Africa jumped southward to the Azores and the locus of convergence between western Eurasia and Africa shifted from the Pyrenees and Alps to its present-day Azores-Gibraltar location [Roest and Srivastava, 1991]. 


\subsection{Late Miocene to Recent Extension}

In the Empordà region of northeastern Spain (Figures 1 and 2), active extension is indicated by Holocene faulting, significant historic seismicity, alkali olivine basaltic volcanism, and twentieth century vertical movements [e.g., Goula et al., 1992; Marti et al., 1992; Giménez et al., 1996]. The principal normal faults in the Empordà region, which are linear and generally shorter than $\sim 40 \mathrm{~km}$ long, strike NW-SE, perpendicular to and younger than the horsts and grabens of the rifted Catalan margin (Figure 3) [e.g., Tassone et al., 1994]. These faults bound the tilted blocks of the Transverse Ranges. Geological and geophysical evidence indicates a clear separation in time between normal faulting in the Empordà and normal faulting in the Gulf of Lion and the València trough [e.g., Vázquez et al., 1993; Saula et al., 1994; Tassone et al., 1994]. No early to middle Miocene extension has been recognized in the region of the Empordà, whereas a minimum of $8.4 \mathrm{~km}$ of total normal separation has developed since $8 \mathrm{Ma}$ [Saula et al., 1994]. Normal faulting has propagated inland a distance of $44 \mathrm{~km}$ from the coast to the Amer-Brugent fault, which forms the western escarpment of the extensional province and is presently the most active normal fault of the system [Goula et al., 1992]. By contrast, the SW-NE striking faults that bound the major Neogene basins of the Catalan Coastal Ranges and offshore grabens of the Valencia trough have undergone only minor neotectonic activity [e.g., Masana, 1994, 1995, 1996]. *

Tortonian $(\sim 11 \mathrm{Ma})$ to Recent normal faulting in this area has been variously attributed to (1) a change in the direction of plate convergence between Africa and Europe, resulting in a SW-NE direction of least principal stress [Vázquez et al., 1993]; (2) intraplate buckling of the lithosphere in response to horizontal stresses derived from convergence between the European and African plates [Vegas, 1994]; and (3) reactivation of an extinct transfer zone between the Gulf of Lion and the València trough [Vegas, 1994].

\subsection{Syncontractional and Postcontractional Topography of the Ebro Basin}

The Catalan margin is characterized by prominent mountain ranges that roughly parallel, and lie $25-50 \mathrm{~km}$ inland from, the shoreline (Figure 2). The Catalan Coastal Ranges parallel the southern, SW-NE trending segment of the Catalan margin, whereas the Transverse Ranges parallel the northern, N-S trending segment [Sole Sabaris and Llopis, 1939]. The highest topographic elevations of the entire margin (the Montseny massif, with peaks over $1700 \mathrm{~m}$ ) lie at the intersection of two major normal fault systems, the SW-NE striking, east dipping normal faults of the Catalan Coastal Ranges and the NW-SE striking, east dipping normal faults of the Transverse Ranges. The Catalan Coastal Ranges are divided into range blocks by Neogene basins bounded on their northern sides by major normal faults [Guimerà, 1984]. These basins (some parallel and some oblique to the Catalan Coastal Ranges) are, from south to north, the Baix Ebre, Mora, El Camp, Penedès and Vallès basins (Figure 3). Both the Emporda and La Selva basins lie east of the Transverse Ranges and are bounded by major normal faults on their SW sides (Figure 3).

In treating the Neogene-Quaternary topographic development of northeastern Iberia it is important to first establish how much of the present-day topography may be related to the syncontractional period. Middle Eocene fan deltas bordering the southeastern margin of the Ebro basin grade into marine strata toward the basin center. These fan-deltas, developed within a foreland basin context, now lie well above sea level and represent development of significant topography after contraction ceased. For example, at Montserrat, nearly $1300 \mathrm{~m}$ of fan delta deposits have been uplifted and tilted toward the northwest, showing maximum topographic elevations of $1236 \mathrm{~m}$. Furthermore, in the area of the Transverse Ranges, Eocene strata dip westward and axes of anticlines and synclines plunge westward as well. These folds date from terminal Pyrenean thrust faulting in late Oligocene time [e.g., Riba et al., 1983].

Between these two areas, although more conjectural, the Montseny massif appears to have undergone a similar uplift history. Four lines of evidence suggest that this topography is also postcontractional: (1) the basin infill resembles stratigraphic sections cut by basin center oil wells [e.g., Vergés et al., 1998], (2) the northeastern continuation of the NE-SW striking frontal thrust of the Catalan Coastal Ranges lies $\sim 25 \mathrm{~km}$ to the southeast of the present basin margin, (3) there is no significant syncontractional deformation within the foreland basin strata in front of the Catalan Coastal Ranges frontal thrust, and (4) both Tertiary foreland strata and their basal unconformity are tilted toward the northwest. In summary, the present topography of the Ebro basin between the thrust fronts of the Catalan Coastal Ranges and the Pyrenees may be treated in this paper as postcontractional.

\section{Geomorphic Features}

In this section we document patterns in the modern river drainage system and in local relief in basin sedimentary rocks, the extent and geometry of elevated topography, and the relationships between normal faults and geomorphic features.

\subsection{River Drainage System}

The modern river drainage system in northeastern Spain comprises several principal catchments, which are separated by drainage divides formed by the coastal mountain ranges that parallel the Catalan margin of the Mediterranean sea (Figure 3). A major drainage divide parallels not only the coast but also the strike of the normal faults that bound Neogene basins of the Catalan margin. This drainage divide has two segments, one segment striking N-S and the other striking NE-SW, generally concordant with the two major systems of normal faults in this area [Vergés et al., 1996]. The divide separates the exterior catchment, drained to the Mediterranean by relatively short, parallel rivers oriented perpendicular to the coastline, and an interior domain of generally $\mathrm{N}-\mathrm{S}$ trending rivers that drain the Pyrenean chain. Within the exterior catchment, some streams are out of equilibrium and are actively regrading their channels, suggesting limited active tectonism within the Catalan Coastal Ranges [Masana, 1994, 1995].

Within the interior catchment we differentiate two subcatchments corresponding to the Llobregat-Ter Rivers and the Ebro River (Figure 3). The Llobregat flows N-S through the Pyrenean foothills, maintaining this course across the Ebro basin and changing direction only slightly to a south-southeasterly course through the Catalan Coastal Ranges, ultimately emptying 


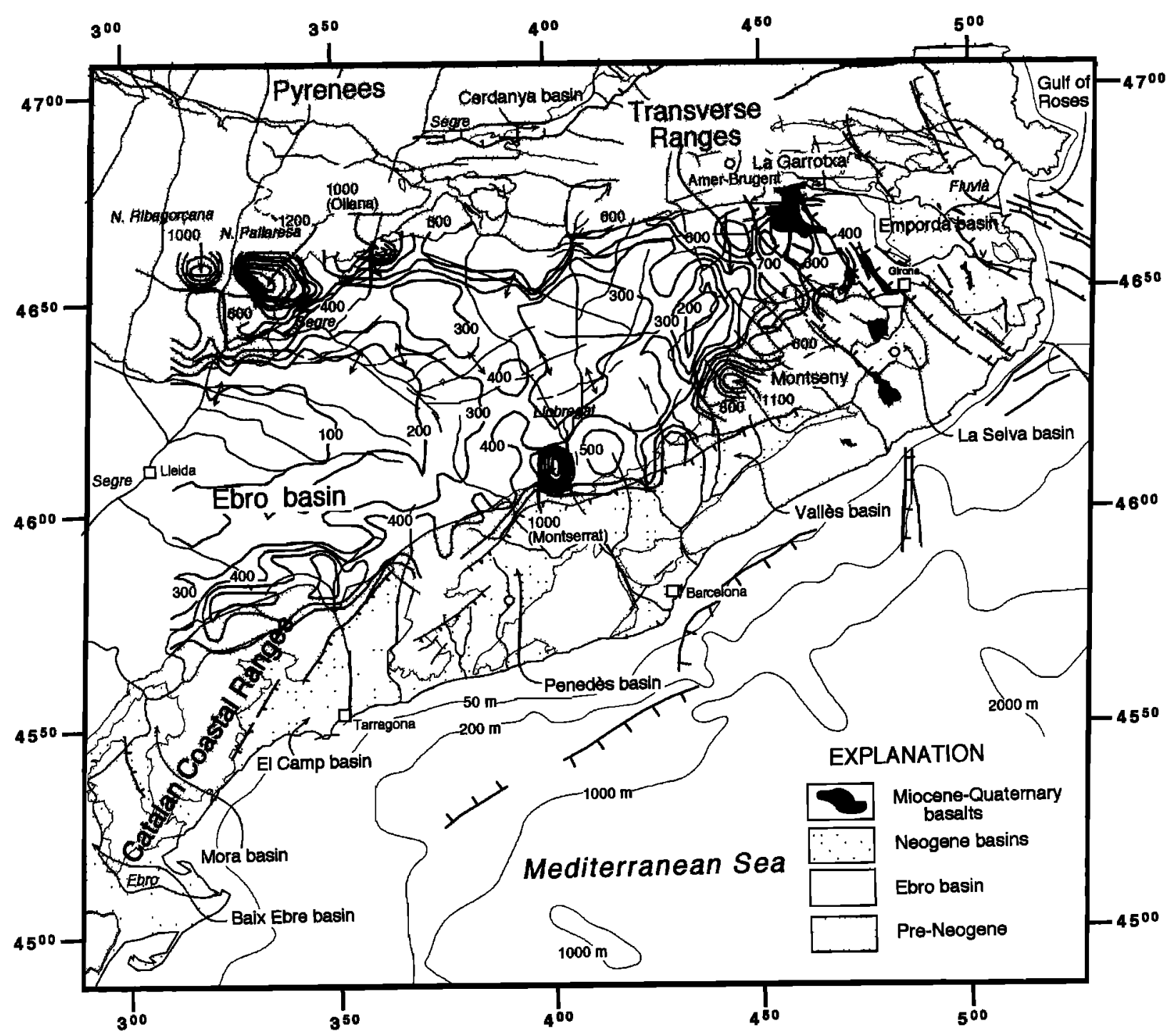

Figure 4. Contoured values of local relief. Line patterns are the same as those in Figure 3 . To quantify incision into basin deposits, we calculated local relief within $(5 \mathrm{~km})^{2}$ units. These digitally contoured values indicate that relief is concentrated near the mountain fronts along the Ebro basin margin. Along the Ebro basin axis, relief increases from $<100 \mathrm{~m}$ at Lleida to $>700 \mathrm{~m}$ near the Amer-Brugent fault and decreases from there eastward to the coast.

into the Mediterranean. The Ter also flows N-S from the axial zone of the Pyrenees but abruptly changes direction from N-S to W-E where it crosses the Transverse Ranges. The course of the Ter transects the major drainage divide separating coastal rivers from interior rivers. The modern courses of the Llobregat and Ter Rivers indicate capture of interior drainages by headward erosion of coastal rivers [Vergés et al., 1996], perhaps influenced by the courses of antecedent streams. Analogous to the Orange River of southwest Africa [Gilchrist et al., 1994], the Llobregat and Ter Rivers breach coastal ranges and connect an interior catchment to the base level of the exterior catchment. Integration of the catchments has directly influenced evolution of both the divides and the fault-bounded escarpments.

In general, the principal rivers of the Ebro catchment (Segre, Noguera Pallaresa, and Noguera Ribagorçana) flow southward
Into the Ebro basin off the Pyrenean front (Figure 3). A system of smaller streams flows westward into the Ebro basin off the western slope of the Catalan Coastal Ranges (Figure 3). The drainage system of the Ebro catchment connects with the exterior where the Ebro breaches the coastal mountain ranges.

\subsection{Local Relief}

A marked feature of the northeastern Ebro basin (the Tertiary foreland basin to the Pyrenees, the Iberian Range, and the Catalan Coastal Ranges, before rifting dismembered the latter) is the striking variation in amounts of local relief, or stream incision (Figure 4). We define relief (following Ahnert [1970]) as the difference between maximum and minimum elevations within a $(5 \mathrm{~km})^{2}$ unit. To quantify incision in the northeastern Ebro basin, 
we contoured values of local relief and superimposed the contours on a generalized geologic map (Figure 4). We focused our analysis on continental sedimentary rocks of the foreland basin to maximize lithologic homogeneity, thus minimizing effects of lithology on erodability and therefore incision. Nevertheless, the largest values of local relief $(>1000 \mathrm{~m})$ are found along the margins of the Ebro basin where streams carve through competent, Eocene-Oligocene conglomeratic deposits (e.g., at Oliana on the Segre River and Montserrat on the Llobregat River; Figure 4). Basement rocks of the Montseny massif also show large local relief $(>1000 \mathrm{~m}$; Figure 4). An axis of minimum local relief is located within the Ebro basin (Figure 4), along which local relief increases from $<100 \mathrm{~m}$ in the southwest (Lleida) to $>700 \mathrm{~m}$ in the northeast (the footwall of the Amer-Brugent fault). Local maxima and minima along this axis are associated with drainage divides (maxima) and river valleys (minima).

\subsection{Elevated Topography}

Using digital elevation data [Servicio Geográfico del Ejército, 1995], we constructed two sets of topographic profiles across the northeastern Ebro foreland basin and adjacent coastal mountain ranges (Catalan Coastal Ranges and Transverse Ranges) to determine the present geometry of topography and its relationship to tectonic features (Figure 5). The first set of topographic profiles consists of twenty-three $30-\mathrm{km}$-wide profiles spaced 10 $\mathrm{km}$ apart in the direction of increasing local relief along the axis of the Ebro basin (Figures 6 and 7). We use the basin center to minimize both the effects of erosional denudation and isostatic rebound [e.g., Heller et al., 1988] of the Pyrenees and variations in relief due to lithologic differences. The mean elevation of profiles wider than $30 \mathrm{~km}$ is strongly influenced by the range fronts of the Pyrenees and the Catalan Coastal Ranges. Narrower profiles would reduce the maximum and mean elevations of some

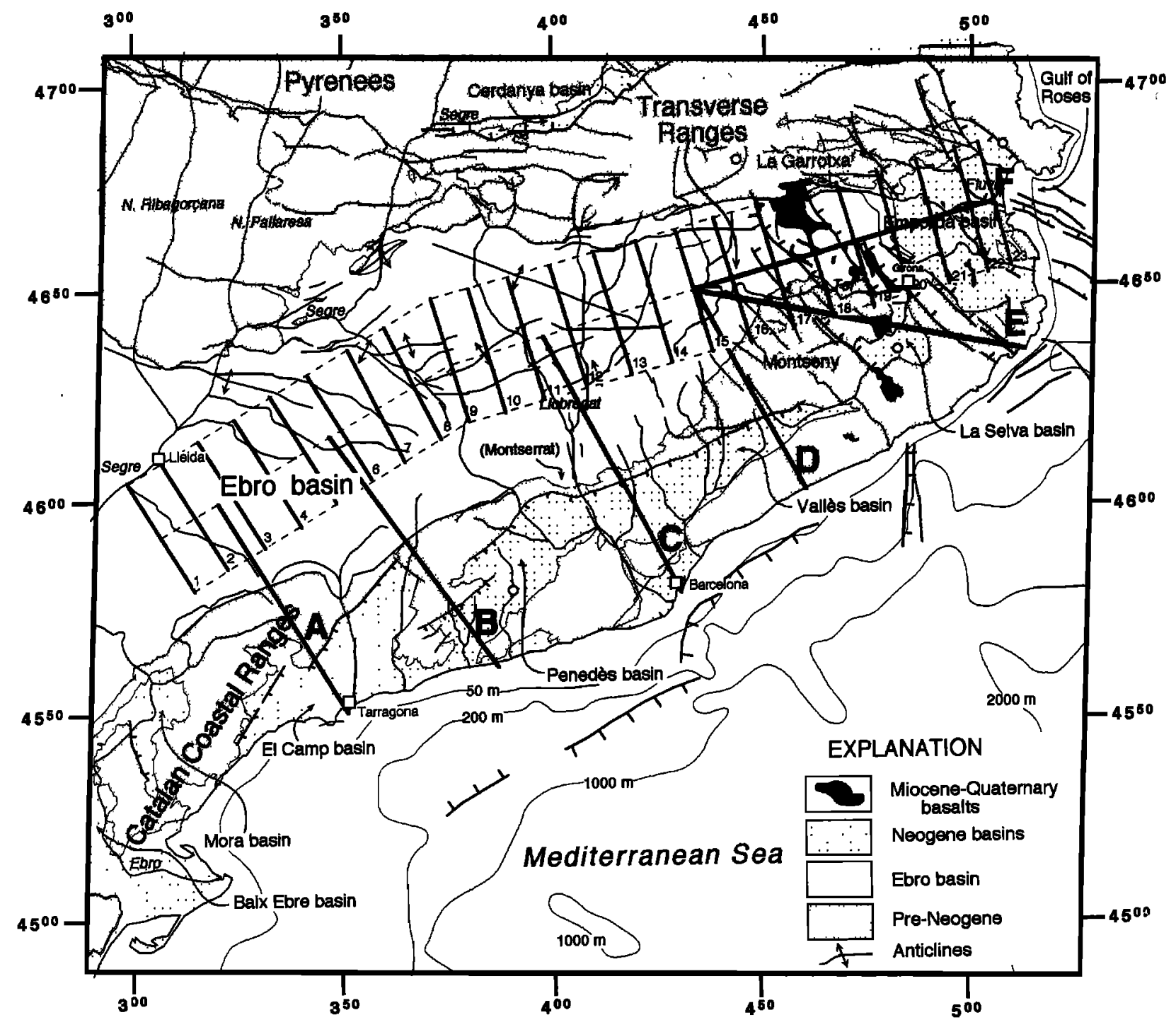

Figure 5. Topographic swath $\sim 230 \mathrm{~km}$ long and $30 \mathrm{~km}$ wide (enclosed by box) divided into 23 segments. Profiles are spaced $10 \mathrm{~km}$ apart. A second set of topographic traverses consists of six profiles (A-F) originating at the Ebro basin center (axis of topographic swath) and ending at the coastline. 


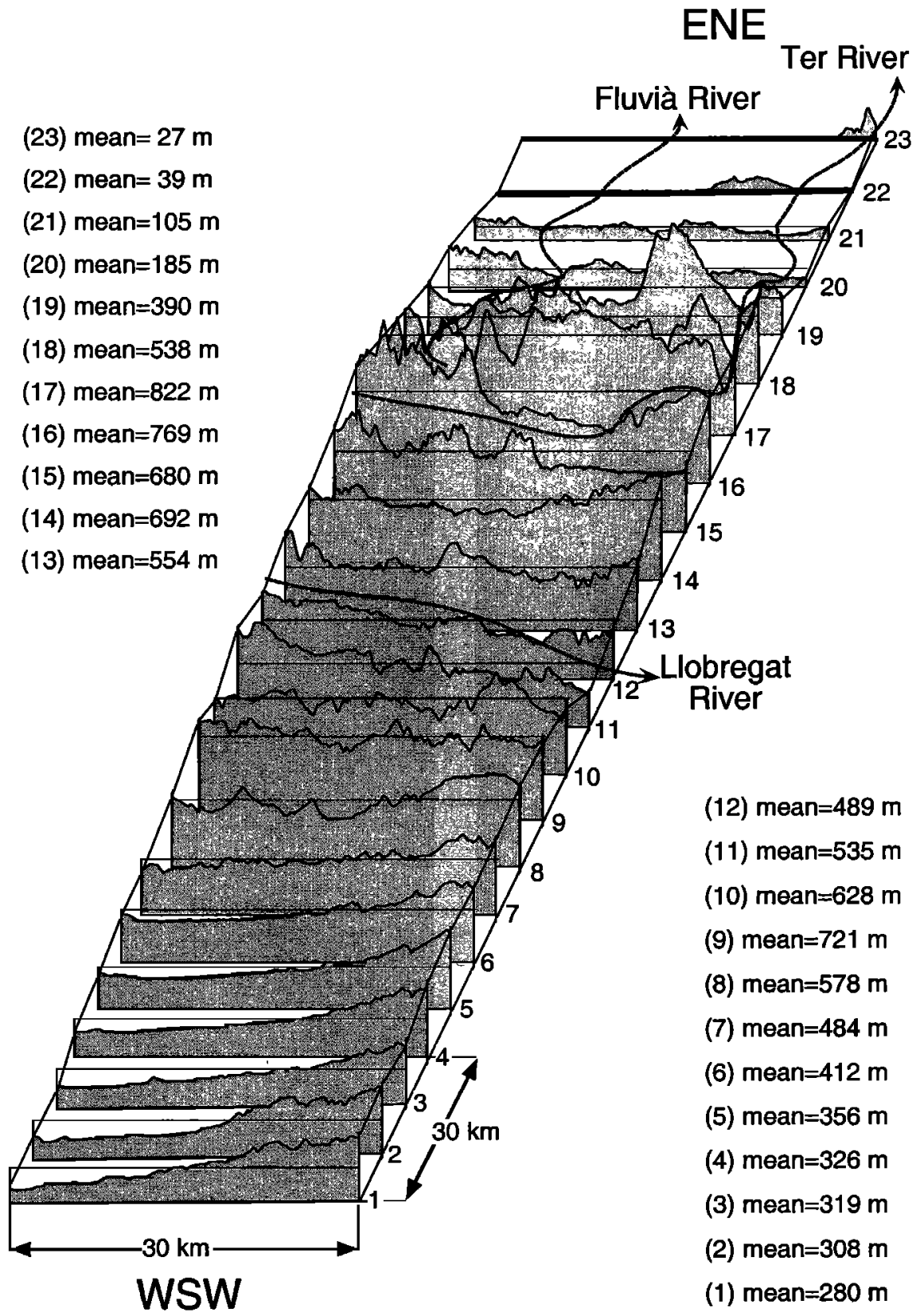

Figure 6. Actual topography of 23 profiles in topographic swath with mean elevation for each indicated by horizontal line. Dashed lines are courses of principal rivers. See Figure 5 for location of profiles 1-23.

profiles, but the trend of increasing mean elevation, perpendicular to drainages, would remain the same.

Determining the relationship between topography and tectonics from these 23 profiles is not straightforward because the topography in each profile results from the interaction of multiple factors, including tectonics, lithology, local climate, and river drainage. At the scale of the entire swath, however, maximum elevation increases gradually from southwest (profile 1) to northeast (profile 17 in the footwall of the Amer-Brugent normal fault) and from there decreases abruptly to sea level at the Mediterranean coast (Figure 7). Minimum elevations approximately mimic mean elevations.
The pattern of mean elevations along the strike of the Ebro basin suggests three domains, bounded by the ends of the swath and maxima in profiles 9 and 17. The western domain shows, in general, an increase of maximum, mean, and minimum elevation from profile 1 to 9 . This general trend may be related to crossing from the undeformed foreland basin into a region of folds and thrust faults detached on top of evaporites [Vergés et al., 1992] along with grain-size coarsening in the same direction. The largest increment in mean elevation in the western domain occurs between profiles 8 and 9 , coincident with the Sanaüja anticline that approximately parallels profile 8 (Figure 5 ). In addition to increasing maximum and mean elevations, the geometry of 


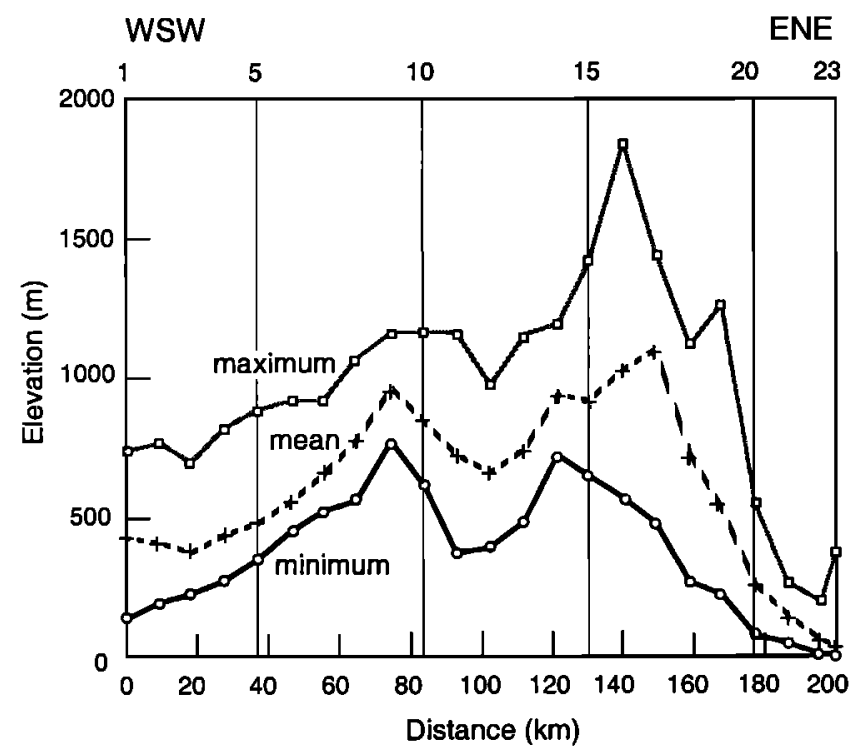

Figure 7. Topographic factors for 23 profiles. Maximum $\left(e_{\max }\right)$, mean $\left(e_{\text {mean }}\right)$, and minimum $\left(e_{\text {mun }}\right)$ elevations for each topographic profile are plotted against distance along the transect. In general, $e_{\text {mean }}$ increases from the western end of the transect to the Transverse Ranges, where the highest mean elevation occurs in the footwall block of the Amer-Brugent fault (profile 16), an active normal fault with $>1 \mathrm{~km}$ of normal separation [Saula $\mathrm{et}$ al., 1994]. The pronounced valley shape in mean elevation between profiles 9 and 17 is due to incision by the Llobregat River. The $\mathrm{e}_{\text {mean }}$ of profile 14 lies above the linear trend due to carbonatecemented sandstones that are resistant to erosion. Lines of profiles are indicated in Figure 5.

profiles 1-8 shows a strong asymmetry with very low elevations at the northern end of these profiles, much higher elevations at the southern ends, and a concave-upward shape (Figure 6).

Elevation trends in the central domain, encompassing profiles 9-17, are more complex, reflecting influences of river drainages, lithology, and extensional faulting. In general, mean elevation increases from southwest to northeast across the central domain. The highest values of maximum, mean, and minimum elevations do not coincide in the same profile. Profile 16 contains the highest elevation peaks $(\sim 1850 \mathrm{~m})$ of the entire swath (Figure 6 ); these peaks correspond to the Bellmunt anticline, a thrust-related fold detached on evaporites. The maximum value of mean elevation ( $822 \mathrm{~m}$, profile 17 ) corresponds to high peaks in the footwall of the Amer-Brugent normal fault, withın the Transverse Ranges (Figures 5 and 6). At the southern end of this range lies the Montseny massif (elevations up to $1700 \mathrm{~m}$ ), composed of crystalline rocks at the intersection between NE-SW and NW-SE normal fault sets. The lowest value of minimum elevation in the central domain is found in profile 11, which intersects the course of the Cardener River, a major tributary of the Llobregat. The lowest values of both maximum and mean elevations nearly coincide in profile 12 owing to the Llobregat River, which crosses the topographic swath between profiles 11 and 12 (Figures 5 and 6). The overall valley shape of the central domain reflects the great erosive power of the Llobregat system. The small decrease in mean elevation from profile 14 to 15 coincides with the Vic plain (profile 15, Figure 6), an extensive erosional surface carved into poorly lithified Eocene marine marls. In contrast to increasing maximum and mean elevations from west to east within the central domain, minimum elevation decreases eastward from profile 14; profiles 14-17 all intersect major river valleys (Figure 6). Mean elevation in the central domain seems the most reliable indicator of the general topographic trend, given the high values of local relief in this sector as shown in Figure 4.

The eastern domain, from profile 17 to 23 , is characterized by a general decrease of maximum, mean, and minimum elevations (Figure 7). Two small peaks in maximum elevation at profiles 19 and 23 represent horst blocks of the Neogene fault system that bounds the Empordà basin (Figures 5 and 6).

In summary, maximum elevation increases from the nearly undeformed foreland in the west to the footwall of the active, NW-SE striking Amer-Brugent fault in the east. Mean elevation shows a more complex pattern influenced by both extensional and compressional tectonics, lithologic changes, and river drainages. However, there is a marked regional increase in mean elevation from $280 \mathrm{~m}$ at profile 1 to $822 \mathrm{~m}$ at profile 17 . This trend is interrupted by pronounced incision produced by the Llobregat and Ter Rivers and their tributaries.

The second set of topographic traverses consists of six profiles (A through $\mathrm{F}$ in Figure 5) originating at the Ebro basin center (axis of our topographic grid) and ending at the coastline (Figure 8). These profiles show the spatial relationships between highest elevation peaks, drainage divides, and principal notmal faults. From SW to NE, profiles A through D cross the Catalan Coastal Ranges and the early Neogene SW-NE striking set of normal faults bounding the El Camp, Penedès, and Vallès grabens (Figure 5). Profile E obliquely crosses the intersection of the Catalan Coastal Ranges and the Transverse Ranges where the Montseny massif lies in the footwall of two orthogonal normal fault systems (Figure 3). Profile F crosses the Transverse Ranges, the neotectonically active Amer-Brugent fault, and other late Neogene-Quaternary NW-SE striking normal faults of the Empordà graben. Independent of their geographic position, all six profiles show a similar geometry (Figure 8). Importantly, all profiles cut stratigraphically downward through the northwesttilted Ebro basin section toward the normal faults (from Miocene to Oligocene to Eocene foreland basin deposits). Concordantly, the degree of exhumation increases from west to east along the profiles. These relations suggest that footwalls of normal faults in this area have undergone flexural uplift. The shape of these flexures can be approximated by curves that join points of maximum elevation along each profile [see Zandt and Owens, 1980; van der Beek et al., 1995]. Flexure shapes for profiles A-F are similar to theoretical flexures and topographic profiles of the Wasatch Front (Utah); [Zandt and Owens, 1980], as well as reconstructed geologic cross sections of other normal fault systems of the Basin and Range province [e.g., Wernicke and Axen, 1988].

Nonetheless, profile F, which crosses the Transverse Ranges, shows a unique arrangement of topographic features compared to profiles crossing the Catalan Coastal Ranges. In the Catalan Coastal Ranges the positions of normal fault, highest topography, and drainage divide are distinct, whereas in profile $F$, highest topography and drainage divide are very close or even coincident (Figure 8). Maximum local relief and drainage divide are located well inland of the Oligocene- and early Miocene-aged [Guimerà, 

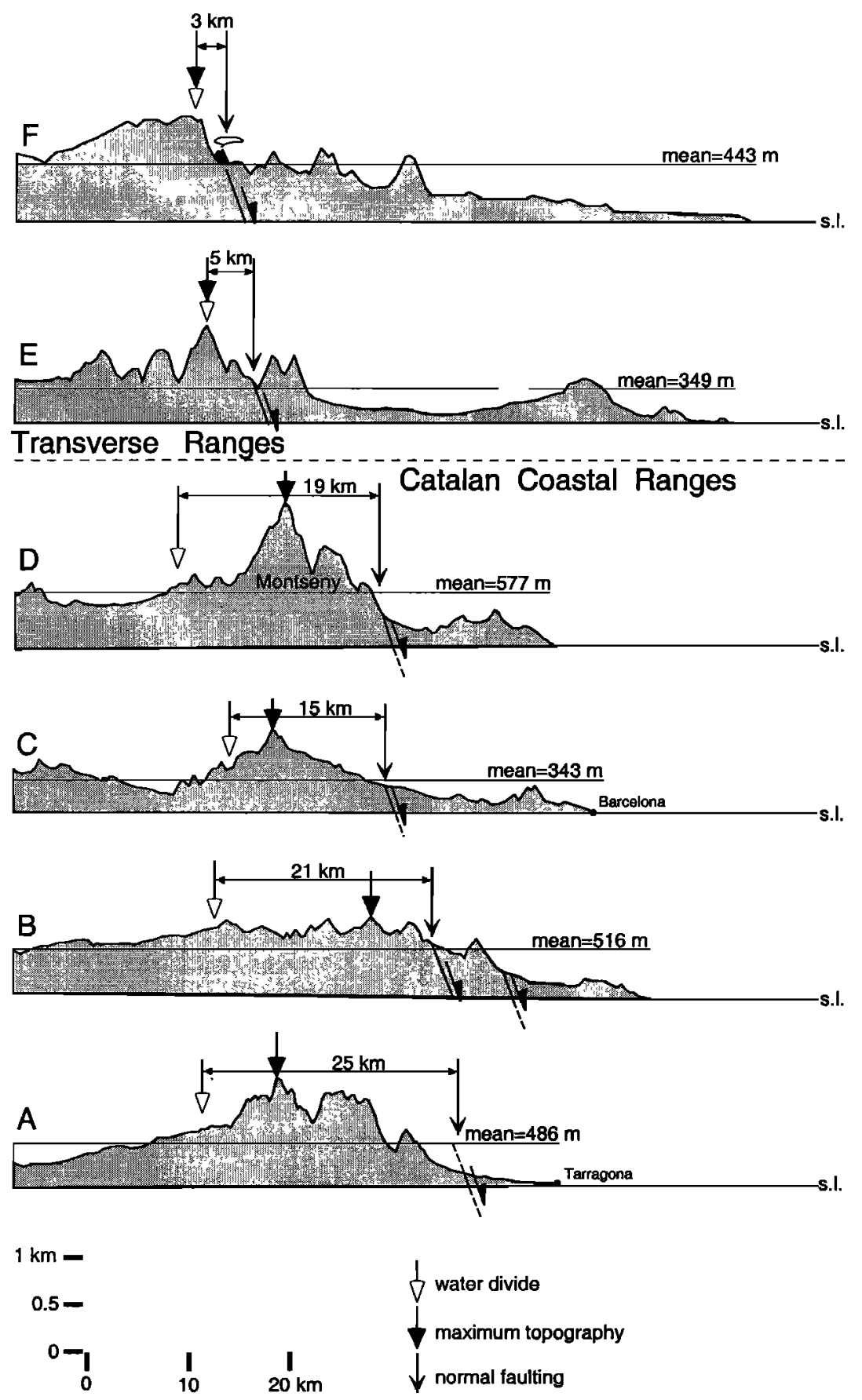

Figure 8. Topographic profiles across the Transverse Ranges and the Catalan Coastal Ranges, showing escarpments separating elevated ranges from low-lying rift basins near the coast. Profiles are aligned at the coastline. We show the actual topography between the endpoints of each profile. Horizontal double-ended arrows mark retreat of fault escarpment due to erosion. Horizontal lines indicate mean elevation of each profile. Lines of profiles are indicated in Figure 5. 


\section{Transverse Ranges}

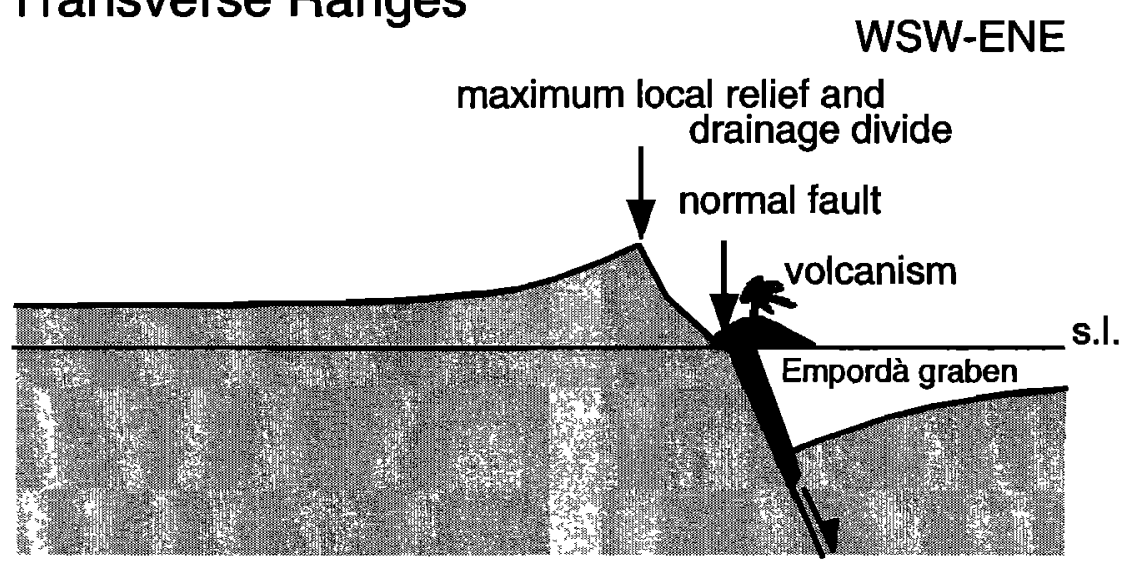

\section{Catalan Coastal Ranges}

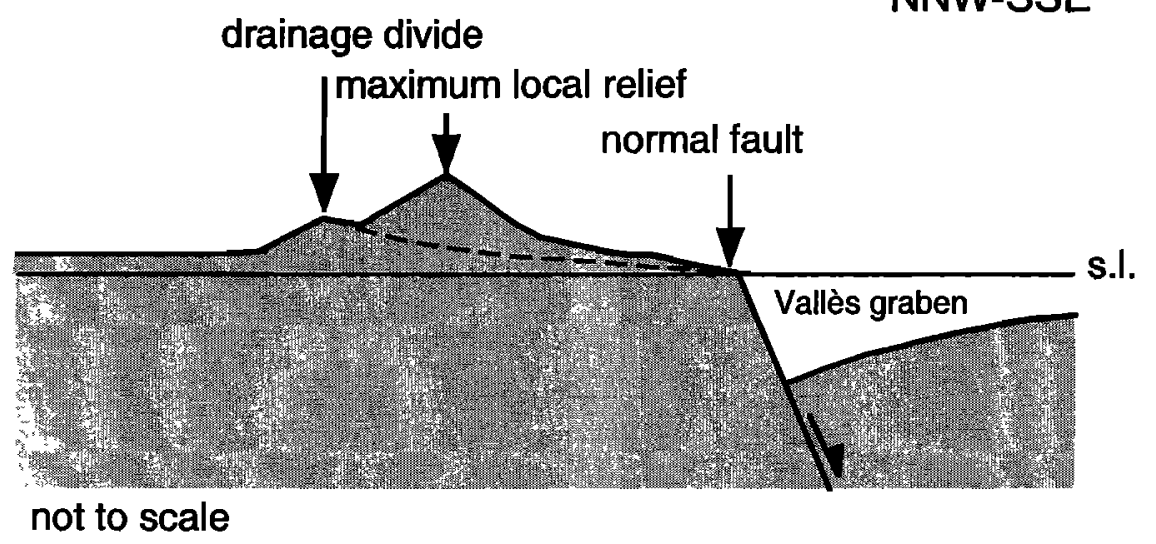

Figure 9. Topographic effects of normal faulting and isostatic rebound, showing positions of normal fault, highest topography, and drainage divide in schematic cross sections. In the Catalan Coastal Ranges these topographic features are spatially separated, whereas highest topography and drainage divide are very close or even coincident in the Transverse Ranges. Positions of topographic features may be largely a function of the age of the normal faulting, Oligocene to early Miocene for the Catalan Coastal Ranges and late Miocene to Quaternary for the Transverse Ranges.

1994; Bartrina et al., 1992] SW-NE striking normal faults [see van der Beek et al., 1995]. On the contrary, the escarpments of NW-SE striking faults, late Miocene to Quaternary in age, have had less time to retreat such that maximum topographic elevations and drainage divide are juxtaposed and close to the trace of the normal fault. We present these spatial relationships schematically in Figure 9, relating topography to normal faults that parallel the NE coast of the Iberian Peninsula (Figures 2 and $3)$.

\section{Geographic Extent of Elevated Topography: Evidence for Dynamic Support of Topography in Northeastern Iberia?}

Geometric analysis of topographic profiles A-F indicates a strong link between topography and extensional tectonics. The spatial relationships between topographic peaks, normal faults, and drainage divides, as well as the overall shape of the topography, give us a qualitative idea of the timing of local landscape evolution related to extension. In this section we combine the results of our topographic analysis with published geological and geophysical data to determine the geographic extent of mountainous topography and/or high values of local relief, links with local and regional tectonics, and landscape evolution at the regional scale. We distinguish two overlapping areas of mountainous topography, a southern area related to late Oligocene to middle Miocene rifting and a northern area related to late Miocene to Quaternary rifting (Figure 10).

Although amounts of rock uplift along the Catalan margin are not well characterized, vitrinite reflectance studies combined with detailed cross-section balancing indicate that $>1.2 \mathrm{~km}$ of postEocene synrift to postrift exhumation has occurred at Montserrat (Figure 4) [López-Blanco, 1993] and that $\sim 2 \mathrm{~km}$ has occurred elsewhere along the southeastern margin of the Ebro basin [Vergés et al., 1998]. Originally horizontal strata display regional tilts toward the center of the Ebro basin with topographic 


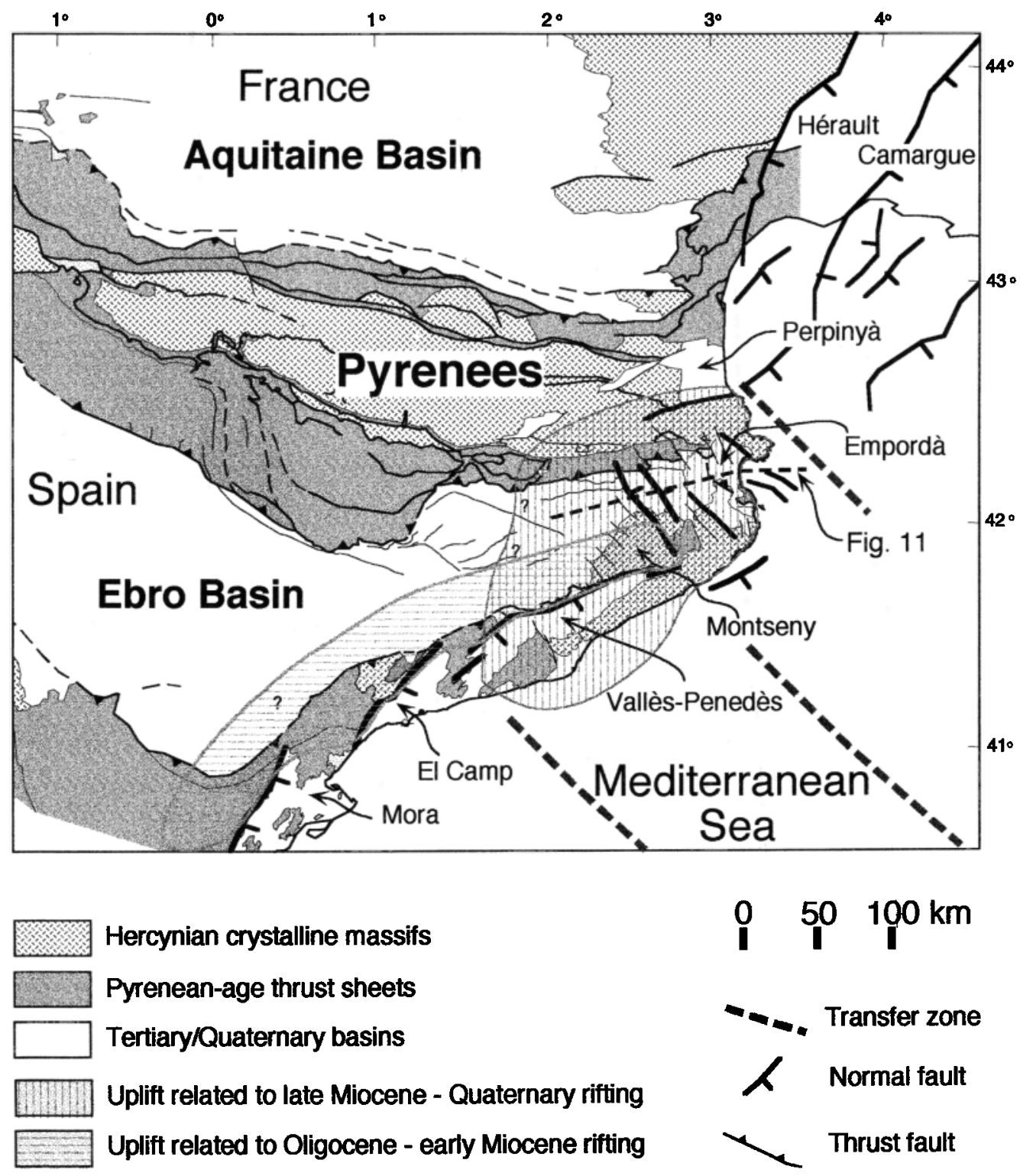

Figure 10. Map of northeastern Iberian Peninsula showing two areas of mountainous topography related to Neogene and Quaternary extension. The southern area is limited to the footwalls of Oligocene-early Miocene normal faults. The northern area is wider and affects both the hanging walls and footwalls of the NW-SE trending late Miocene-Quaternary normal faults. The Montseny massif is located in the region of overlap between the two areas of elevated topography.

profiles showing concave-up curvature typical of footwall flexures in rift shoulder regions (Figures 6 and 8). The effects of rift shoulder uplift therefore encompass the Catalan Coastal Ranges and extend about $25-35 \mathrm{~km}$ into the Ebro basin (horizontal ruled pattern, Figure 10). Rift-related topography seems to extend toward the south (beyond the limits of our study area) along the coastline and the trend of the Neogene system of faults that created the northern border of the València trough. This large-scale system of normal faults parallels the prerift Catalan Coastal Ranges and is nearly orthogonal to the southwestern termination of the Iberian Range [Julivert et al., 1974].
By analogy with other rifted margins [e.g., Gilchrist et al., 1994], the process of rifting along the Catalan margin has acted as an important control on drainage patterns and denudation. We propose that the escarpments that border the Catalan margin originated at least in part by mechanical unloading and isostatic rebound of the lithosphere during extension. In the Catalan Coastal Ranges, erosion plays a significant role in maintaining mountain ranges produced by late Oligocene to middle Miocene rifting. Erosion continuously renews topography while at the same time causing retreat of the normal fault escarpments into the Ebro basin.

On the other hand, topography associated with the active 
Amer-Brugent fault is youthful and likely results from mechanical unloading of the footwall of the normal fault. Total normal separation on the Amer-Brugent fault is between $\sim 1000$ and $1400 \mathrm{~m}$ [Saula et al., 1994]. Because little erosion of the footwall has occurred, the shape of the flexure is preserved and suggests that uplift due to footwall rebound extends westward a distance of $\sim 15 \mathrm{~km}$ (Figure 8). However, trends in maximum and mean elevation and local relief, all of which increase between Lleida and the Amer-Brugent fault, indicate that youthful topography extends some $150 \mathrm{~km}$ from the Mediterranean coast westward into the Ebro basin (Figure 10). The map distribution of geological units indicates regional westward inclination of bedding and exhumation of Paleogene foreland basin strata in the Transverse Ranges [Clavell et al., 1988; ICC, 1989]. Very gentle westward dips persist in Miocene strata located $25 \mathrm{~km}$ or more west of Lleida (Figure 3). Although the spatial link between mountainous topography and normal faults is clear, the broad extent of elevated and incised topography in northeastern Spain, extending more than $90 \mathrm{~km}$ westward of the Amer-Brugent fault (Figure 10), suggests as well regional surface uplift associated with active extension and volcanism west of the Empordà region.

Superposed effects of long-term footwall isostatic rebound and regional surface uplift linked to active extension and volcanism should be most apparent where the two effects overlap. The Penedès and Vallès basins, for example, show evidence of active uplift, including incision of rivers and thin, discontinuous Quaternary terrace deposits [Masana, 1994], implying that uplift has been the predominant process during Quaternary times. The southern extent of regional surface uplift is indicated by extensive Quaternary deposition in the southern part of the Penedès basin [ICC, 1989] as well as recent subsidence of $\sim 2.5 \mathrm{~mm} / \mathrm{yr}$ over the last 45 years in the same area (1877 to 1922 leveling surveys) [Giménez et al., 1996]. In addition, the El Camp, Mora, and Baix Ebre basins farther south show widespread Quaternary deposition, indicating long-term subsidence beyond the limits of dynamically or thermally induced surface uplift. Modest active incision of rivers into the uppermost Quaternary river terraces is likely due to Holocene climatic changes.

The Empordà basin contains evidence for competition between subsidence related to active rifting and surface uplift. The principal faults of the Empordà basin have experienced longterm, mean, down-to-the-east displacement of $\sim 1 \mathrm{~mm} / \mathrm{yr}$ over the last 10 Myr (based on Saula et al. [1994]). Leveling surveys carried out at both ends of the Amer-Brugent fault indicate rates of vertical offset (down-to-the-east) of $\sim 4 \mathrm{~mm} / \mathrm{yr}$ within the last 50 years [Giménez et al., 1996]. Nevertheless, the Empordà basin shows only limited Quaternary deposition adjacent to the Gulf of Roses, and the majority of the rivers are incised into Pliocene deposits. Regional surface uplift thus appears to dominate extension-related subsidence.

Further evidence for dynamic/ thermal support of topogiaphy comes from basement massifs in northeastern Spain. Maximum elevations along the Catalan margin coincide, in the Montseny massif and easternmost Pyrenees, with very high values of local relief. In part, high elevations in the Montseny massif may be due to the massifs position at the intersection of two orthogonal, active normal fault systems (Figure 4): the NW-SE striking Amer-Brugent fault and the SW-NE striking northern Vallès fault. Recent activity on the easternmost segment of the northern Vallès fault is known from analysis of geomorphic factors such as river gradient and incision indices (Figure 4); [Masana, 1994]. Recent activity on the Amer-Brugent fault is indicated by historic seismicity [Goula et al., 1992], by offsets detected by leveling surveys [Giménez et al., 1996], and by the youthfulness of the landscape as indicated by the close proximity of normal fault, drainage divide, and topographic maximum in the footwall (Figure 9). Overlapping effects of tectonic and erosional denudation likely produce enhanced isostatic rebound of this footwall block. Nevertheless, exposures of Hercynian basement rocks at Montseny, where elevations exceed $1700 \mathrm{~m}$, represent the deepest levels of exhumation in the Catalan Coastal Ranges. Furthermore, Precambrian schists, the oldest rocks in the axial zone of the Pyrenees, are exposed near the easternmost end of the Pyrenees, where valleys are eroded nearly to sea level and yet maximum elevations exceed $2000 \mathrm{~m}$ [Fonteilles and Guitard, 1988]. We propose that patterns of local relief, exhumation, and Quaternary sedimentation outlined above are best explained by dynamically or thermally induced surface uplift, associated with active extension and volcanism to the west of the Empordà region.

\section{Discussion}

Regionally, seismic refraction data show that the crust thins from $\sim 55 \mathrm{~km}$ beneath the central Pyrenees to $\sim 30 \mathrm{~km}$ beneath the northern end of the Amer-Brugent fault to $\sim 22 \mathrm{~km}$ at the Mediterranean coast (Figure 11) [Daignières et al., 1982]. Seismic refraction and gravity data show that the Pyrenees, underlain by a thick crustal root, are in approximate isostatic equilibrium, whereas the mountainous topography of the Catalan Coastal Ranges and Transverse Ranges is not supported by crustal roots [Daignières et al., 1982; Morgan and Fernàndez, 1992]. This has also been demonstrated in the onshore segment of the Estudios Sísmicos de la Corteza Ibérica (ESCI) deep seismic profile across the Catalan Coastal Ranges [e.g., Vidal et al., 1997; Sàbat et al., 1997]. If we assume a pre-extension crustal thickness of $55 \mathrm{~km}$ for the eastern Pyrenees (similar to the central Pyrenees), a present-day crustal thickness of $22 \mathrm{~km}$ beneath the 2000-m-high eastern Pyrenees implies $33 \mathrm{~km}$ of crustal thinning. The buoyancy loss implied by crustal thinning of this magnitude would lower elevations by some $4500 \mathrm{~m}$. Without a large buoyancy contribution from the mantle, $22-\mathrm{km}$ thick crust will not support a 2000-m mountain range.

Many authors have concluded that thinning of the deep lithosphere beneath northeastern Iberia has caused changes through time in basalt geochemistry and significant thermal uplift [e.g., Morgan and Fernàndez, 1992; Watts and Torné, 1992; Janssen et al., 1993]. Recent modeling of gravity and geoid data shows that the lithosphere is $\sim 75-80 \mathrm{~km}$ thıck beneath the Catalan margin and thins to $\sim 60 \mathrm{~km}$ at the axis of the València trough [Ayala et al., 1996]. Similarly, gravity and geoid modeling beneath the Empordà region indicates that the lithosphere thins from $\sim 65 \mathrm{~km}$ beneath the Transverse Ranges to $\sim 50 \mathrm{~km}$ at the coastline (Figure 11; C. Ayala, unpublished data, 1996). This represents $35-50 \%$ thinning of typical Iberian lithosphere $(\sim 100$ km thick; Pino and Helmberger [1997]). Some of this thinning is accounted for by crustal extension, but significant thinning of the mantle lithosphere is required by geophysical data [e.g., Foucher et al., 1992; Morgan and Fernàndez, 1992]. Convective removal of mantle lithosphere is strongly suggested by $\mathrm{Nd}-\mathrm{Sr}$ isotopic data 


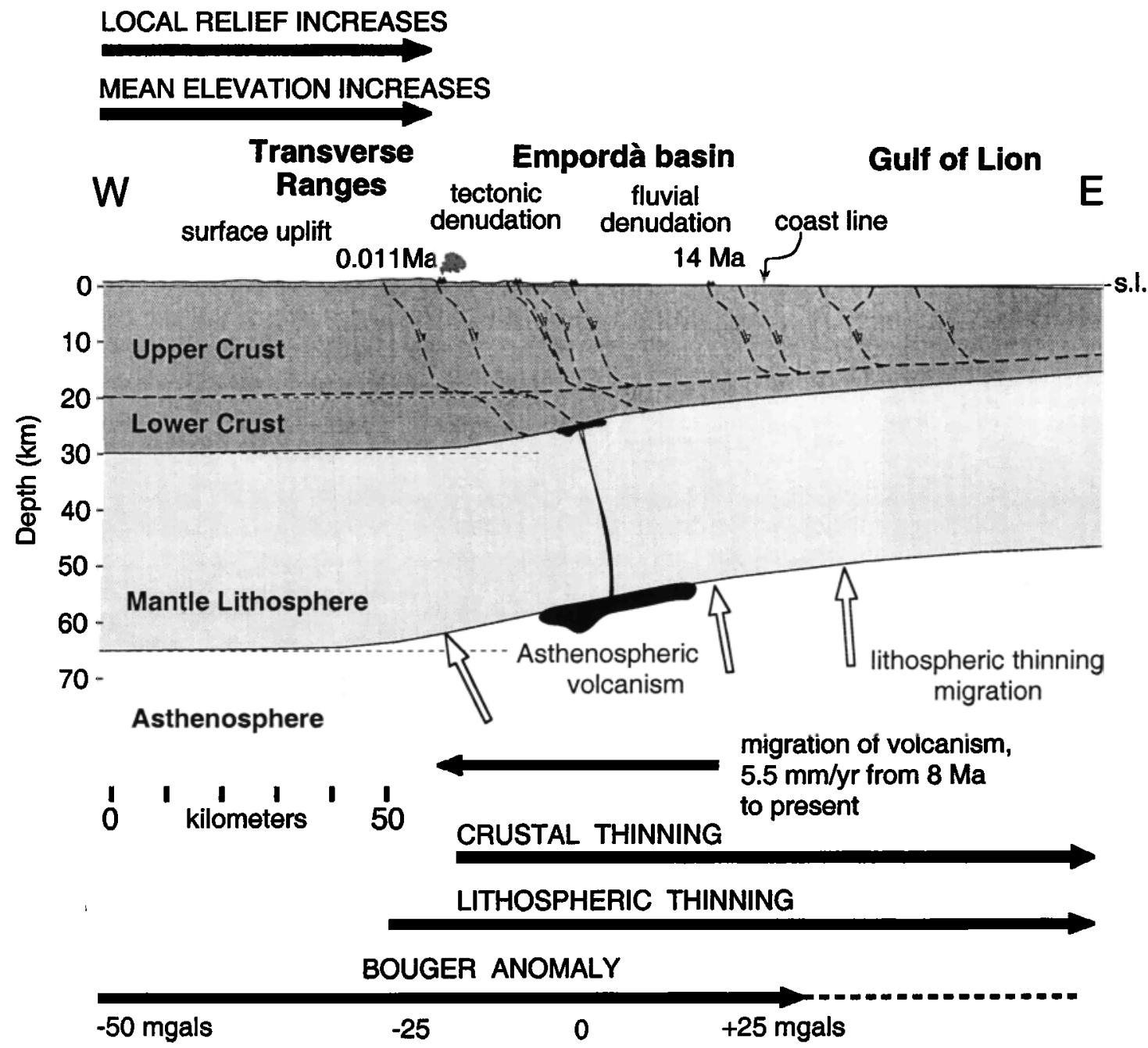

Figure 11. Lithospheric section showing interrelated surficial and deep-seated processes (line of the section in Figure 10). The section shows the increase of local relief and mean elevation in the footwall of the Amer-Brugent fault as well as the direction of increasing crustal and lithospheric thinning. Crustal thickness has been determined from seismic refraction data [Daignières et al., 1982]. Lithospheric structure is based on gravity modeling [Casas et al, 1986, 1997] and geoid modeling [C. Ayala, unpublished data, 1996]. The geometry of the normal faults is based on the work of Saula et al. [1994]. The geometry of asthenospheric and subcrustal magma chambers has been schematically drafted on the basis of the work of Neumann et al. [1999]. The age of migration of the volcanism is based on the work of Saula et al. [1994] and Lewis et al. [1998]. Westward migration of extension and volcanism into the peninsula may be due to mechanical removal of the mantle lithosphere, as proposed for the Rio Grande rift, United States [Perry et al., 1988]. Buoyancy forces due to migration of anomalous mantle may cause regionalscale doming of the crust centered on the neotectonically and volcanically active region west of the Empordà basin.

from middle to upper Miocene alkaline basalts of Empordà which indicate depleted asthenospheric sources, and therefore lithospheric thicknesses of $<70 \mathrm{~km}$, as early as $12 \mathrm{Ma}$ [Lewis et al., 1998], prior to substantial crustal thinning in the Empordà basin. Lithospheric thinning of this magnitude, replacing cold mantle with warm mantle, may be adequate to balance the crustal thinning and account for present-day mountainous topography up to $2000 \mathrm{~m}$ [e.g., Ducea and Saleeby, 1996].

Geophysical evidence from the València trough indicates anomalously warm mantle beneath the region, which may provide the required buoyancy. Modeling of the negative geoid anomaly that characterizes the Valencia trough suggests a major thermal (density) boundary in the mantle lithosphere at the Catalan margin [Watts and Torné, 1992]. Anomalously low subcrustal $\mathrm{P}$ wave velocities of 7.6-7.8 $\mathrm{km} / \mathrm{s}$ beneath the Valencia trough and Catalan margin are attributed to extensive heating of the mantle during rifting [Pascal et al., 1992; Torné et al., 1996]. Bouguer gravity anomalies, however, increase from $-50 \mathrm{mGals}$ west of the Transverse Ranges to $+25 \mathrm{mGals}$ at the coastline [Casas et al., 1986] and exceed $+130 \mathrm{mGals}$ in the València trough [Watts and Torné, 1992]. The anomaly is positive because the mass deficiency associated with hot, low-density mantle beneath the 
region is obscured by the effects of density contrasts within the crust and a thick sediment load.

Seismic tomographic studies show large-scale, lateral density variations in the mantle beneath western Europe, presumably caused by horizontal temperature variations [e.g., Snieder, 1988; Spakman et al., 1993; Hoernle et al., 1995]. A 2500-km-wide zone of low-velocity upper mantle is thought to extend from the eastern Atlantic Ocean to central Europe [Hoernle et al., 1995]. This anomaly, interpreted as an inclined sheet of convecting mantle, has been cited as the origin of the $2000-\mathrm{km}$-long western European rift, which parallels the strike of the sheet. Isotopic data from young volcanic rocks of the eastern Atlantic, the western Mediterranean, and central Europe suggest a common asthenospheric source related to this "plume" [e.g., Hoernle et al., 1995]. Active extension, earthquakes, asthenosphere-derived volcanism, crustal and mantle lithospheric thinning, and anomalous topography in northeastern Iberia may be ongoing manifestations of deep-seated heating related to convecting, anomalous mantle. Migration of alkaline volcanism and extension $44 \mathrm{~km}$ into the peninsula over the last $8 \mathrm{Myr}$ (based on Saula et al. [1994]), a rate of $5.5 \mathrm{~mm} / \mathrm{yr}$ [Vergés et al., 1996], may indicate migration of a thermal anomaly and/or convective thinning of mantle lithosphere over time (Figure 11). On the basis of the relations detailed above, we suggest that buoyancy forces created by lateral density differences in the mantle [see Wernicke et al., 1996] augment the effects of tectonic and geomorphic forcing in creation of youthful topography in this area. Our schematic cross section in Figure 11 combines topography, geology, and geophysical data in a model to explain this youthful topography. Geological and geophysical evidence from the region thus points toward a deep lithospheric or asthenospheric cause for active extension and volcanism and suggests partial dynamic or thermal support of mountainous topography in northeastern Spain.

\section{Conclusions}

Much of the present configuration of the northeastern Iberian Peninsula derives from Neogene opening of the València trough and adjacent westem Mediterranean basins following the Pyrenean orogeny. Topographic analysis along the southwesterly plunging Ebro basin axis shows high values of local relief along the southeastern margin (footwall of the Oligocene to middle Miocene Catalan fault system) and the eastern margin (footwall of the late Miocene to Recent Empordà fault system). The increase in local relief northeasterly along the basin axis is accompanied by an increase in mean elevation. Local relief, characteristics of the river drainage system, location of drainage divides, and degree of escarpment retreat indicate that a principal cause of elevated topography along the Catalan margin is flexural isostatic rebound due to tectonic and erosional denudation, causing exhumation of the rifted margin. Footwall uplift, river drainage development, and erosion linked to intersecting normal fault systems produced the present form of the Catalan Coastal Ranges and the Transverse Ranges with maximum elevations in the Montseny massif where two major normal fault systems intersect. Topography of the Transverse Ranges, however, is younger than that of the Catalan Coastal Ranges, where crustal extension and landscape evolution have longer histories. Nevertheless, exhumation, by tectonic or erosional means, is not adequate to explain the extent of incised topography nor the presence of high mountains in a zone of thinned crust, suggesting a component of dynamic and/ or thermal support of mountainous topography, likely from density differences in the mantle. Westward migration of extension and volcanism into the peninsula may be due either to migration of a thermal anomaly or to mechanical removal of the mantle lithosphere. Any geodynamic models of the evolution of the western Mediterranean region must consider these links between surficial features and mantle processes.

Without more detailed information on the timing and amount of uplift, we cannot assess the relative importance of tectonic, geomorphic, and geodynamic factors. This can be gained from fission track analysis integrated with regional stratigraphic, gravity, and seismic data. In addition, a seismic tomographic study centered on the Empordà region would be useful in delineating the magnitude and shape of seismic velocity anomalies beneath this area.

Acknowledgments. We thank members of the former Departament de Geologia Dinàmica, Geofisica i Paleontologia of the Barcelona University and the Institute of Earth Sciences "Jaume Almera" (Barcelona) for stimulating discussions about this work. We thank Clement G. Chase, Lidia Lonergan, and Adrian Pfiffner for their helpful reviews. We also thank Conxi Ayala for the modeling and Bernat Ferrús for help with figures. A Fulbright Fellowship and a Los Alamos National Laboratory Director's Postdoctoral Fellowship funded C. Lewis. Los Alamos National Laboratory contribution number LA-UR 996014. This work was partially supported by Grups de Recerca Consolidats (II Pla de Recerca de Catalunya) project 1997 SGR 00020 to J. Vergés.

\section{References}

Ahnert, F., Functional relationships between denudation, relief, and uplift in large mid-lattude drainage basins, $A m$. J. Sci., 268, 243-263, 1970.

Alvarez, W., T. Cocozza, and F. C. Wezzel, Fragmentation of the Alpine orogenic belt by microplate dispersal, Nature, 248, 309-314, 1974.

Anadón, P, L. Cabrera, J. Gumerá, and P. Santanach, Paleogene strike-slip deformation along the southeastern margin of the Ebro basin, in Strike-Slip Tectonics and Sedimentation, edited by K. T. Biddle and N. Christie-Blick, Spec. Publ. Soc. Econ. Paleontol. Minkral., 37/303-318, 1985.

Ayala, C., J. Pous, and M Torné, The lithosphereasthenosphere boundary of the València trough (western Mediterranean) deduced from 2D geoid and gravity modelling, Geophys. Res. Lett., 23, 3131-3134, 1996
Bartrina, M. T., L. Cabrera, M. J. Jurado, J. Gummerà, and E. Roca, Evolution of the central Catalan margin of the Valencia trough (westem Mediterranean), Tectonophysics, 203, 219-247, 1992.

Buck, W. R., Small-scale convection induced by passive nftung: The cause for uplift of rift shoulders, Earth Planet. Sci Lett., 77, 362-372, 1986.

Buck, W. R, F. Martinez, M S Steckler, and J. R. Cochran, Thermal consequences of lithosphenc extension: Pure and simple, Tectonics, 7, 213-234 1988.

Casas, A., M. Tomé, and E. Banda, Mapa Gravimètric de Catalunya, $135 \mathrm{pp}$., scale 1:500,000, Dep. de Polit. Territ. i Obres Públıques, Serveı Geol. de Catalunya, Barcelona, Spain, 1986.

Casas, A., P. Kearey, L. Rivero, and C. R. Adam, 1997, Gravity anomaly map of the Pyrenean region and a comparison of the deep geological structure of the westem and eastern Pyrenees, Earth Planet. Sci. Lett., 150, 65-78.

Cherchi, A., and L. Montadert, Oligo-Miocene rift of Sardinia and the early history of the western Mediterranean Basin, Nature, 298, 736-739, 1982.

Choukroune, P., and ECORS-Pyrenees Team, The ECORS-Pyrenean deep seismic profile reflection data and the overall structure of an orogenic belt, Tectonics, 8, 23-29, 1989.

Clavell, E., A. Martinez, and J Vergés, Morfologia del basament del Pireneu oriental: Evolucio i relació amb els mantels de corriment, Acta Geol. Hisp., 23, 129-140, 1988.

Cravatte, J., P. Dufaure, M. Prim, and S Rouaix, Les sondages du golfe du Lion: Stratigraphe, 
sédımentologie, Notes Mem., /l, pp. 209-274, Co. Fr. des Pétroles, Paris, 1974

Daignières, M, J Gallart, E. Banda, and A. Hirn, Implications of the seismic structure for the orogenic evolution of the Pyrenean Range, Earth Planet Sci. Lett., 57, 88-100, 1982.

Dewey, J. F., M. L. Helman, E Turco, D. H. W. Hutton, and S. D. Knott, Kinematics of the western Mediterranean, in Alpine Tectonics, edited by M. P. Coward, D. Dietrich, and R. G. Park, Geol. Soc. Spec Publ. London, 45, 265-283, 1989.

Ducea, M. N., and J. B. Saleeby, Buoyancy sources for a large, unrooted mountain range, the Sierra Nevada, California: Evidence from xenolith thermobarometry: J. Geophys. Res., 101, 8229-8244, 1996.

Ebinger, C. J., T. D. Bechtel, D. W. Forsyth, and C. O. Bowin, Effective elastic plate thickness beneath the East African and Afar Plateaus and dynamic compensation of the uplifts, J. Geophys. Res., 94, 2883-2901, 1989.

ECORS-Pyrenees Team, The ECORS deep reflection seismic survey across the Pyrenees, Nature, 33I, 508-511, 1988.

Fonteilles, M., and G. Guitard, Precambrian basement in the Variscan belt of the Pyrenees, in Precambrian in Younger Fold Belts, edited by V. Zoubek, pp. 553573, John Wiley, New York, 1988.

Foucher, J. P., A. Mauffret, M. S. Steckler, M. F. Brunet, A. Maillard, J. P. Rehault, B. Alonso, P. Desegaulx, J. Murilas, and G. Ouillon, Heat flow in the Valencia Trough: Geodynamic implications, Tectonophysics, 203, 77-97, 1992.

Gilchrist, A. R., and M. A. Summerfield, Differential denudation and flexural isostasy in formation of rifted-margin upwarps, Nature, 346, 739-742, 1990.

Gilchrist, A R., H. Kooi, and C. Beaumont, PostGondwana geomorphic evolution of southwestem Africa: Implications for the controls on landscape development from observations and numerical experiments, J. Geophys. Res., 99, 12,211-12,228, 1994.

Guménez, J , E. Suriñach, J. Fleta, and X. Goula, Recent vertical movements from high-precision leveling data in northeast Spain, Tectonophysics, 263, 149-161, 1996.

Gorin, C., A. Mauffret, and A. Le Marrec, Contribution to the structural and sedimentary history of the Gulf of Lion (western Mediterranean) from the ECORS profiles, industrial seismic profiles and well data, Bull. Soc. Geol. Fr., 164(3), 353-363, 1993.

Goula, X., C. Olivera, J. Escuer, J. Fleta, B. Grellet, and J. C. Bousquet, Neotectonics and seismicity in the area of the seismic crisis of 1427-1428 in Catalonia, Proceedings of the 22nd General Assembly of the European Seismological Commission, Barcelona, Spain, 1992.

Gumerà, $\mathrm{J}$, Paleogene evolution of deformation in the northeastem Iberian Peninsula, Geol. Mag., 121, 413-420, 1984.

Gumerà, J., Cenozoic evolution of eastern Iberia Structural data and dynamic model, Acta Geol. Hisp., 29, 57-66, 1994.

Heller, P. L., C. L. Angevine, and N. S. Winslow, Twophase stratigraphic model of foreland-basin sequences, Geology, 16, 501-504, 1988.

Hoemle, K., Y. S. Zhang, and D. Graham, Seismic and geochemical evidence for large-scale mantle upwelling beneath the eastern Atlantic and western and central Europe, Nature, 374, 34-39, 1995.

Houseman, G., and P. C. England, A dynarncal model of lithosphere extension and sedimentary basin formation, J. Geophys. Res., 9I, 719-729, 1986.

ICC, Mapa geologic de Catalunya, scale 1:250.000, Inst Cartogr de Catalunya, Barcelona, Spain, 1989.

Janssen, M. E, M. Tomé, S Cloetıngh, and E. Banda, Pliocene uplift of the eastem lberian margin: Inferences from quantitative modeling of the València trough, Earth Planet. Sci. Lett., 119, 585 597, 1993.

Julivert, M., M. Fontboté, A. Ribeiro, and L. Conde, Mapa tectónico de la Península Ibérica y Baleares,
Inst. Geol. y Minero de Esp., Madrid, Spain, pp. 1$113,1974$.

Kooi, H., J. Burrus, and S. Cloetingh, Lithospheric necking and regional isostasy at extensional basins, 1, Subsidence and gravity modeling with an application to the Gulf of Lions margin (SE France) J. Geophys. Res., 97, 17,533-17,571, 1992.

Lewis, C. J., W. S. Baldndge, and Y. Asmerom, Neogene asthenosphere-derived volcanism and NEdirected extension in NE Span: Constraints on the geodynamic evolution of the westem Mediterranean, Eos Trans. $A G U, 79(17)$, Spring Meet. Suppl., S336-S337, 1998 .

Lonergan, L., and N. Whte, Origin of the Betic-Rif mountain belt, Tectonics, 16, 504-522, 1997.

López-Blanco, M., Stratigraphy and sedimentary development of the Sant Llorenc del Munt fan-delta corrplex (Eocene, southem Pyrenean foreland basin, northeast Spain), Spec.l Pub. Int. Assoc. Sedimentol., 20, 67-88, 1993.

Marti, J., J. Mitjavila, E. Roca, and A. Aparicio, Cenozoic magmatism of the Valèncla trough. Relationship between structural evolution and vulcanism, Tectonophysics, 203, 145-165, 1992.

Masana, E., El análisis de la red fluval en el estudio de la neotectónica en las Cadenas Costeras Catalanas. in Geomorfología en España, edited by J. Amaez, J. M. Garcia Ruiz, and A. Gomez Villar, pp. 29-41, Soc. Esp de Geomorfolog., Logroño, Spain, 1994.

Masana, E., L'activitat neotectonica a les Cadenes Costaneres Catalanes, Ph.D. thesis, 448 pp., Univ. de Barcelona, Barcelona, Spain, 1995.

Masana, E., Evidence for past earthquakes in an area of low historic seismicity: The Catalan coastal ranges, NE Spain, Ann. Geofis., 39, 689-704, 1996.

Mauffret, A., G. Pascal, A. Maillard, and C. Gorini, Tectonics and deep structure of the north-western Mediterranean Basin, Mar. Pet. Geol., 12, 645-666, 1995.

Montigny, E., J. B. Edel, and R. Thuizat, Oligo-Miocene rotation of Sardinia: K-Ar ages and paleomagnetic data of Tertiary volcanics, Earth Planet. Sci. Lett. 54, 261-271, 1981.

Morgan, $P$, and $M$ Fernảndez, Neogene vertical movements and constraints on extension in the Catalan Coastal Ranges, Iberian Peninsula, and the València trough (western Mediterranean), Tectonophysics, 203, 185-201, 1992.

Muñoz, J. A., Evolutıon of a continental collision belt: ECORS-Pyrenees crustal balanced cross-section, in Thrust Tectonics, edited by K. McClay, pp. 235246, Chapman and Hall, New York, 1992.

Neumann, E-R., J. Marti, J Mitjavila, and E. WulffPedersen, Origin and implications of mafic xenoliths associated with Cenozoic extension-related volcanissn in the València trough, NE Spain, Mineral. Petrol., 65, 113-139, 1999.

Parmentier, E. M., Dynamic topography in rift zones: implications for lithospheric heating, Philos. Trans. R. Soc London., Ser. A, 321, 23-25, 1987.

Pascal, G., M. Torné, P Buhl, A. B. Watts, and A Mauffret, Crustal and velocity structure of the València trough (wesiern Mediterranean), Part II, Detailed interpretation of five expanding spread profiles, Tectonophysics, 203, 21-35, 1992.

Perry, F. V., W. S. Baldridge, and D. J. DePaolo, Chemical and isotopic evidence for lithospheric thinning beneath the Rio Grande rift, Nature, 332, 432-434, 1988.

Pino, N. A., and D. V. Helmberger, Upper mantle compressional velocity structure beneath the west Mediterranean Basin, J Geophys. Res., I02, 29532967, 1997.

Puigdefabregas, $\mathbf{C}$., and $\mathbf{P}$ Souquet, Tectonosedimentary cycles and depositional sequences of the Mesozoic and Tertiary from the Pyrenees Tectonophysics, 129, 173-203, 1986.

Rehault, J. P., G. Boillot, and A. Mauffret, The westem Mediterranean basin: Geological evolution, Mar. Geol., 55, 447-478, 1984 .

Riba, O., S. Reguant, and J. Villena, Ensayo de sintesis estratigráfica y evolutiva de la cuenca terciaria del Ebro, in Libro Jubilar JM Rios. Geol de España, vol. II, 131-159, Instıtuto Geológico y Minero de España, Madnd, 1983.

Roca, E., and P. Desegaulx, Analysis of the geological evolution and vertical movements in the València trough area, westem Mediterranean, Mar. Pet. Geol., 9, 167-185, 1992

Roest, W. R., and S. P. Srivastava, Kinematics of the plate boundaries between Eurasia, Iberia, and Africa in the North Atlantic from the Late Cretaceous to the present, Geology, 19, 613-616, 1991.

Roure, F., P. Choukroune, X. Berastegur, J A Muñoz, A. Villien, $P$. Matheron, M Bareyt, M. Seguret, P. Cámara, and J Déramond, ECORS deep seismic data and balanced cross sections: Geometnc constraints on the evolution of the Pyrenees, Tectonics, 8, 41-50, 1989.

Royden, L., Evolution of retreating subduction boundaries formed during continental collision, Tectonics, /2, 629-638, 1993.

Sàbat, F., E. Roca, J A. Muñoz, J Vergés, P Santanach, E. Masana, M. Sans, A. Estévez, and C. Santisteban, Role of extension and compression in the evolution of the eastern margin of Iberia. The ESCI-València trough sessmic profile, Rev. Soc. Geol. Esp., 8(4), 431-448, 1997.

Saula, E., J. Picart, E. Mató, M. Llenas, M. Losantos, X. Beràstegui, and J. Agusti, Evolución geodınámica de la fosa del Empordà y las Sierras Transversales, Acta Geol. Hisp., 29, 55-76, 1994.

Servicio Geográfico del Ejército, Carta digital de España, Madrid, Spain, 1995.

Snieder, R., Large-scale waveform inversions of surface waves for lateral heterogeneity, 2, Application to surface waves in Europe and the Mediterranean, $J$. Geophys. Res., 93, 12,067-12,080, 1988.

Solé Sabaris, L, and N Llopis, Termınación septentrional de la Cordillera Costera Catalana, Asociación para el Estudio de Geología del Mediterraneo Occidental, VI(I), 1-85, 1939.

Spakman, W., S. van der Lee, and R. van der Hilst, Travel-time tomography of the EuropeanMediterranean mantle down to $1400 \mathrm{~km}, P$ hys. Earth Planet. Inter, 79, 3-74, 1993.

Stephenson, R., and K. Lambeck, Erosion-isostatic rebound models for uplift: An application to southeastem Australia, Geophys. J. R. Astron. Soc., 82, 31-55, 1985 .

Tassone, A., E. Roca, J. A Muñoz, L Cabrera, and M. Canals, Evolución del sector septentnonal del margen continental catalán durante el Cenozóıco, Acta Geol. Hisp., 29, 3-38, 1994.

Tomé, M., E. Banda, and M. Femàndez, The Valèncıa trough: geological and geophysical constraints on basin formation models, in Structure and Prospects of Alpine Basins and Forelands, edited by P. A Ziegler and F. Horvàth, Mem. Mus. Natl Hist. Nat., Paris, I70, 103-128, 1996.

Tucker, G. E., and R. L. Slingerland, Erosional dynamics, flexural isostasy, and long-lived escarpments: A numerical modeling study, $J$. Geophys. Res., 99, 12,229-12,243, 1994.

van der Beek, P., S. Cloetingh, and P. Andriessen, Mechanisms of extensional basin formation and vertical motions at rift flanks: Constraints from tectonic modeling and fission track thermochronology, Earth Planet. Sci. Lett., I2I, 317-330, 1994.

van der Beek, P., P. Andriessen, and S. Cloetingh, Morphotectonic evolution of rifted continental margins: Inferences from a coupled tectonic-surface processes model and fission track thermochronology, Tectonics, 14, 406-421, 1995.

Vázquez, T, T. Medialdea, and R. Vegas, El sistema NW-SE de fosa de Rosas y Bagur (margen continental nororiental de Esparla), Geogaceta, 14, 21-23, 1993.

Vegas, R., A tectonic model for the volcanic province of Olot (NE Spain), Geogaceta, 15, 121-123, 1994

Vergés, J., Estudi tectonic del vessant Sud del Pirineu 
Oriental i Central: Evolucio en 3D, Ph.D. thesis, 203 pp., Univ, de Barcelona, Barcelona, Spain, 1993.

Vergés, J., and D. W. Burbank, Eocene-Olıgocene thrusting and basin configuration in the eastern and central Pyrenees (Spain), in Tertiary Basins of Spain, edited by P. F. Friend and C. J. Dabrio, Cambridge University Press, Cambridge, England, pp. 120-133, 1996.

Vergés, $\mathbf{J}$, and Sàbat, F. Constraints on the western Mediterranean kinematic evolution along a 1,000-km transect from Iberia to Africa, in The Mediterranean basins: Tertiary extension within the Alpine orogen, edited by $B$ Durand, L. Jolivet, F. Horväth, and $M$ Séranne, pp. 63-83, Geol. Soc. Spec. Publ, 156, in press.

Vergés, J., J. A. Muñoz, and A. Martínez, South Pyrenean fold-and-thrust belt: Role of foreland evaporitic levels in thrust geometry, in Thrus Tectonics, edited by $\mathrm{K}$. McClay, pp. 255-264, Chapman and Hall, New York, 1992.

Vergés, J., H. Millán, E. Roca, J. A. Mừioz, M. Marzo, J. Cirés, T. Den Bezemer, R. Zoetemejuer, and S Cloetingh, Eastern Pyrenees and related foreland basins: Pre-, syn-, and post-collisional crustal-scale cross-sections, Mar. Pet. Geo., 12, 893-915, 1995.

Vergés, J., C. Lewis, and M. Marzo, Fluvial dranage and topography related to extension: NE of Iberia, Geogaceta, 20, 850-852, 1996.

Vergés, J., M. Marzo, T Santaeulària, J. Serra-Kiel, D. W. Burbank, J A. Muñoz, and J. GiménezMontsant, Quantified vertical motions and tectonic evolution of the SE Pyrenean foreland basin, in Cenozoic Foreland Basins of Western Europe, edited by A. Mascle et al., Geol. Soc. Spec. Publ., 132, 107-134, 1998

Vidal, N., J. Gallart, and J. J Dañobeitia, Contnbutıon of the ESCI-València trough wide-angle data to a crustal transect in the NE Iberian margin, Rev. Soc. Geol.a Esp., 8(4), 417-429, 1997.

Vigliotti, L., and V. E. Langenheim, When did Sardinia stop rotating?: New palaeomagnetic results, Terra Nova, 7, 424-435, 1995.

Watts, A. B., and M. Tomé, Subsidence history, crustal structure, and thermal evolution of the Valencia trough: A young extensional basin of the westem Mediterranean, J. Geophys. Res., 97, 20,021$20,041,1992$.

Wdowinski, S., and G. J. Axen, Isostatic rebound due to tectonic denudation: A viscous flow model of a layered lithosphere, Tectonics, $/ 1,303-315,1992$.

Weissel, J. K., and G. D. Kamer, Flexural uplift of rift flanks due to mechanical unloading of the lithosphere during extension, J. Geophys. Res., 94, 13,919-13,950, 1989.

Wemicke, B., and G. J. Axen, On the role of isostasy in the evolution of normal fault systems, Geology, 16, 848-851, 1988.

Wernicke, B., et al., Origin of high mountains in the continents: The southem Sierra Nevada, Science, 27I, 190-193, 1996.

Zandt G., and T. J. Owens, Crustal flexure associated with normal faulting and implications for seismicity along the Wasatch Front, Utah, Bull. Seismol. Soc. Am., 70, 1501-1520, 1980

C. J. Lewis, Los Alamos National Laboratory, EES1, MS D462, Los Alamos, NM 87545. (clewis@lanl.gov)

M. Marzo, Departament d'Estratigrafia i Paleontologia, Universitat de Barcelona, Martí i Franquès $s / n, 08028$ Barcelona, Spain.

J. Vergés, Institute of Earth Sciences "Jaume Almera," CSIC, Lluís Solé i Sabarís s/n, 08028 Barcelona, Spain.

(Received October 19, 1998; revised July 2, 1999;

accepted July $17,1999$. . 